\title{
Champa Citadels: An Archaeological and Historical Study
}

\author{
Đỗ Trường Giang \\ Studies (IICS) \\ giangiseas@gmail.com \\ Suzuki Tomomi \\ Archaeological Institute of Kashihara, Nara, Japan \\ grow_b_t@hotmail.com \\ Nguyễn Văn Quảng \\ Hue University of Sciences, Vietnam \\ quangkch@gmail.com \\ Yamagata Mariko \\ Okayama University of Science, Japan \\ yamariko@mgt.ous.ac.jp
}

National University of Singapore, Singapore and Institute of Imperial Citadel

\begin{abstract}
From 2009 to 2012, a joint research team of Japanese and Vietnamese archaeologists led by the late Prof. Nishimura Masanari conducted surveys and excavations at fifteen sites around the Hoa Chau Citadel in Thua Thien Hue Province, built by the Champa people in the ninth century and used by the Viet people until the fifteenth century. This article introduces some findings from recent archaeological excavations undertaken at three Champa citadels: the Hoa Chau Citadel, the Tra Kieu Citadel in Quang Nam Province, and the Cha Ban Citadel in Binh Dinh Province. Combined with historical material and field surveys, the paper describes the scope and structure of the ancient citadels of Champa, and it explores the position, role, and function of these citadels in the context of their own nagaras (small kingdoms) and of mandala Champa as a whole. Through comparative analysis, an attempt is made to identify features characteristic of ancient Champa citadels in general.
\end{abstract}




\section{Keywords}

Cha Ban - Champa - citadel - Hoa Chau - Thanh Cha - Thanh Ho - Thanh Loi Tra Kieu

\section{Tra Kieu Citadel in Quang Nam}

Among the ancient citadels of Champa located in central Vietnam, the Tra Kieu site in Quang Nam has generally been identified as the early capital, and thus has attracted the interest of many scholars. Tra Kieu is about 28 kilometers south of Da Nang city, and about 18 kilometers inland from the mouth of the Thu Bon River as the crow flies. It is situated between two UNESCO World Heritage sites: Hoi An Ancient Town, about 13 kilometers northeast of Tra Kieu, and My Son Sanctuary, about 14 kilometers to the southwest. Located along the Thu Bon River valley, the three are assumed to have constituted the axis of a regional polity called Amaravati, in which Hoi An functioned as a port, Tra Kieu as a political center, and My Son as a religious center. ${ }^{1}$

The Tra Kieu site extends along the southern bank of a small tributary of the Thu Bon River, in Duy Xuyen District, Quang Nam Province (Fig. 1). It is surrounded by almost rectangular-shaped ramparts. The southern rampart stretches about 1500 meters east-west; the width of the citadel measures about 550 meters north-south. ${ }^{2}$ The well-preserved southern and eastern ramparts are about 2-3 meters higher than the present paddy fields, with a width at the bottom of about 33 meters. The northern and western ramparts are depicted on the map of Tra Kieu made by the French archeologist Claeys in the 1920s, but these ramparts can hardly be recognized on the ground today. ${ }^{3}$

1 Trần Quốc Vượng, "Miền Trung Việt Nam và văn hóa Champa" (Central Vietnam and Champa Culture), Nghiên cứu Đông Nam Á (Southeast Asian Studies) 4 (1995): 8-24.

2 Nishimura reported that the length of the southern rampart measured 1,420 meters and the north-south width of the citadel about 510 meters. Nishimura Masanari, ed., Basic Study on the Citadel and Fort Sites of Dai Viet and Champa: The Second Southeast Asian Archaeology Data Monograph [Japanese] (Yamaguchi: Foundation to Safeguard the Underground Cultural Heritage in Southeast Asia, 2013), 102.

3 Jean-Yves Claeys, "Fouilles de Tra-Kieu," Bulletin de l'Ecole française d'Extrême Orient 27 (1928): 468-482. 


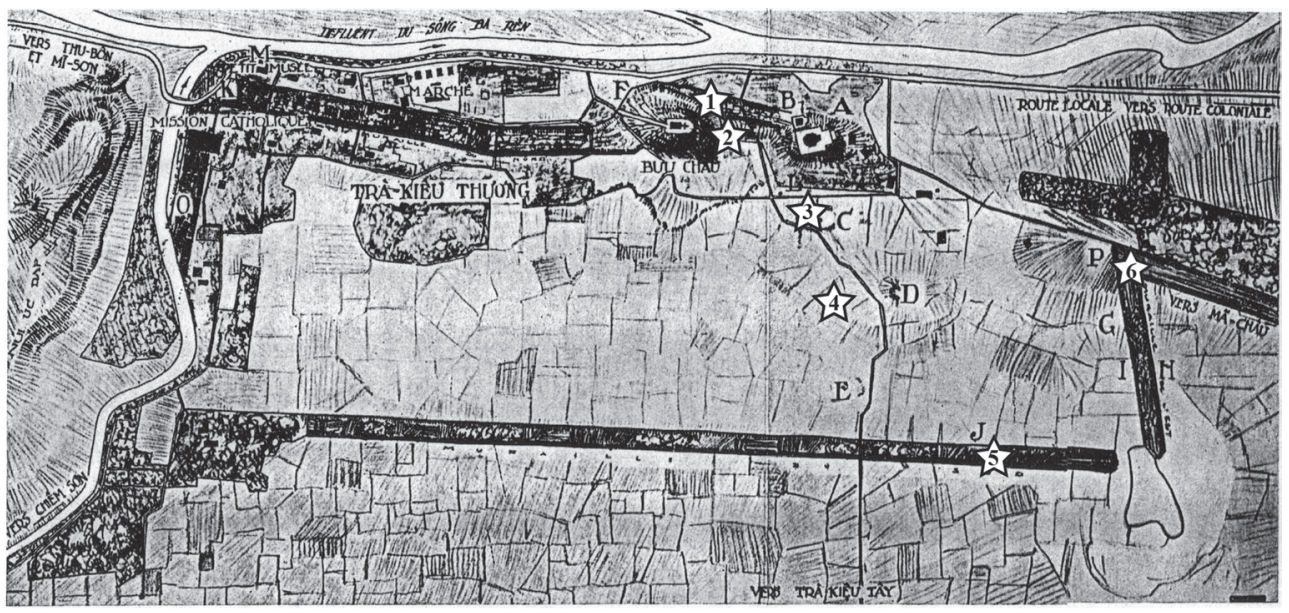
$200 \mathrm{~m}$

FIGURE 1 Map of Tra Kieu showing locations excavated after 1990. (1) Buu Chau Northeast (1990, 1993); (2) Buu Chau East (1996); (3) Hoan Chau (1997-20oo); (4) Go Du De (1996); (5) Southern Rampart (1990, 2003); (6) Eastern Rampart.

MAP SOURCE: CLAEYS, "FOUILlES DE TRA-KIEU," FIG. 3, MODIFIED BY YAMAGATA MARIKO.

Claeys carried out extensive excavations at Tra Kieu in 1927-28. ${ }^{4}$ He uncovered large-scale structural foundations, altar bases, lingam and yoni stones, large quantities of stone sculptures, and other items. He seems to have been convinced that Tra Kieu was the capital of Linyi, generally identified as Champa. However, it is now thought that most of the building remains and statues that he excavated can be dated to the ninth through eleventh centuries. ${ }^{5}$

After a long period of war, Vietnamese archaeologists at Ha Noi National University renewed the excavations at Tra Kieu in 1990. They conducted excavations on the northeastern slope of Buu Chau Hill, situated in the middle of the village spreading over the northern half of the citadel. ${ }^{6}$ In 1990 and 2003, they carried out excavations on the southern rampart of Tra Kieu.

4 Ibid.; Jean-Yves Claeys, "Fouilles de Tra-Kieu," Bulletin de l'Ecole française d'Extrême Orient 29 (1929): 578-596; idem, "Simhapura. La grande capitale chame (site de Tra Kieu, Quang Nam, Annam)," Revue des Arts Asiatiques 7 (1931): 93-104.

5 Ian C. Glover, "The Excavations of J.-Y. Claeys at Tra Kieu, Central Vietnam, 1927-1928: From the unpublished archives of the EFEO, Paris and records in the possession of the Claeys family," Journal of the Siam Society 85, parts 1-2 (1997): 177, 183.

6 Nguyễn Chiều et al., "Khai quật di chỉ Chăm cổ ở Trà Kiệu (Quảng Nam—Đà Nẵng)" (Excavation of the Ancient Cham Site at Tra Kieu, Quang Nam, Da Nang Province), Nhũng 
In 1993, a team of Vietnamese, British, and Japanese archaeologists began working at Tra Kieu. The team (including one of the authors, Yamagata) excavated three locations: the northeastern slope of Buu Chau Hill in 1993, a location called Go Du De in the middle of the paddy fields in 1996, and a site called Hoan Chau, located in a village, from 1997 to $2000 .{ }^{7}$ The results of these excavations inside the citadel allowed us to recognize a clear transition in the artifact assemblage unearthed from the lowest to the upper layers, probably dating from the second and third centuries CE. ${ }^{8}$

In 2013, the Yamagata and the Southern Institute of Social Sciences in Ho Chi Minh City launched an archaeological project to investigate the eastern rampart of Tra Kieu. The team conducted two seasons of excavations on the rampart, aiming to verify its date and layout. One of the ultimate goals was to identify archaeological features and artifacts of the fourth century and onward that had not yet been uncovered by the excavations since 1990 in the inner citadel. In the preliminary report of the excavation of the southern rampart by the Ha Noi National University, it is presumed that the construction of the rampart most likely began in the fourth century.

The construction of ramparts in the capital of Linyi is possibly mentioned in juan 97 of Jinshu and in juan 36 of Shuijingzhu. The king of Linyi, Fan Yi, died in $336 \mathrm{CE}$ and his throne was usurped by a former slave of Chinese origin named Fan Wen (r. 336-349). He was reportedly born in the lower Yangtze River region and eventually entered the service of the king of Linyi. Fan Wen built a palace for Fan Yi, and intriguingly, also built chengyi (城邑), which may refer to fortifications. ${ }^{9}$ If Fan Wen constructed the ramparts of the capital, the construction should be dated to the fourth century CE.Juan 36 of Shuijingzhu also reports that "the city walls of Linyi had four gates. By the main gate, which faced to the east, there was an ancient inscription in a foreign

phát hiện mới về khảo cổ học năm 1990 (New Discoveries of Archaeology in 1990) (Hanoi: Nhà xuất bản khoa học xã hội, 1991), 237-239.

7 Yamagata Mariko, ed., The Ancient Citadel of Tra Kieu in Central Vietnam: The Site and the Pottery, Kanazawa Cultural Resource Studies 14 (Kanazawa: Center for Cultural Resource Studies, Kanazawa University, 2014).

8 Yamagata Mariko, "The Early History of Lin-i viewed from Archeology," Acta Asiatica 92 (2007): 1-30; idem, "Tra Kieu during the Second and Third Centuries CE: The Formation of Linyi from an Archaeological Perspective," in The Cham of Vietnam: History, Society, and Art, ed. Tran Ky Phuong and Bruce M. Lockhart (Singapore: National University of Singapore Press, 2011), 81-101.

9 Keith W. Taylor, The Birth of Vietnam (Berkeley: University of California Press, 1983), 106-107. 
script, extolling the virtues of an earlier king named Fan Huda." ${ }^{10}$ Fan Huda reigned from 380 to $413 \mathrm{CE}$.

As for the chronology of early Tra Kieu, Yamagata, one of the authors, previously identified three phases at Hoan Chau, a location in the inner citadel of Tra Kieu, namely, the Lowest, Lower, and Upper Hoan Chau phases." ${ }^{11}$ Later, the Lowest and Lower phases were combined, as they represented a strong contrast with the Upper phase in terms of roof tiles. ${ }^{12}$ Thus, these phases have been renamed Tra Kieu I Phase (subdivided into Ia and Ib) and Tra Kieu II Phase.

As for the characteristics of these phases, Tra Kieu I Phase has a range of pottery of coarse fabric, including ovoid jars, cord-marked jars, lids, dishes, bowls, pedestal cups and stoves, and roof tiles with textile impressions on the concave surface. Particularly in the earliest Phase Ia, ovoid jars and roof tiles with textile impressions are predominant, most likely associated with the very first occupants at Tra Kieu. The authors have not encountered any cultural layer preceding this phase in the inner citadel.

Tra Kieu II Phase is distinct from Tra Kieu I Phase, especially in terms of roof tiles. Roof tiles of Phase II never have textile impressions on the concave surface, reflecting an alternative manufacturing method applied by craftsmen of this phase. The intriguing eaves tiles (end tiles) decorated with human faces at Tra Kieu belong to Tra Kieu II Phase (Fig. 2) and are associated with tiles without textile impressions. ${ }^{13}$ Taking into account the similarity between tiles decorated with a human face at Tra Kieu and those uncovered in Nanjing, the capital of the Six Dynasties in China, ${ }^{14}$ those found in Tra Kieu can be dated from the third century $\mathrm{CE}$, probably from the second quarter onwards.

Tiles, including eaves tiles decorated with human faces, have also been uncovered in the excavation pits on the eastern ramparts of Tra Kieu. Our initial observations have led us to think that these tiles may have appeared later than those excavated at some locations in the inner citadel, such as Buu Chau

$10 \quad$ Fukami Sumio, "Indianization' and the Establishment of Monsoon Voyaging in Maritime Southeast Asia: An Examination of Faxian's Three Homeward Voyages," Intercultural Studies 49 (2014): 33-34.

11 Yamagata, "The Early History of Lin-i."

12 Yamagata, The Ancient Citadel of Tra Kieu in Central Vietnam, 14.

13 Yamagata Mariko and Nguyen Kim Dung, "Ancient Roof Tiles Found in Central Vietnam," in 50 Years of Archaeology in Southeast Asia: Essays in Honour of Ian Glover, ed. B. Bellina, E. A. Bacus, T. O. Pryce, and J. W. Christie (Bangkok: River Books, 2010), 194-205.

14 He Yunao, "Tile Ends with Human and Animal Faces of the Six Dynasties unearthed in Nanjing" [Chinese], Wenwu 2003, no. 7 (2003): 37-44; Eaves Tiles of the Six Dynasties and Capital Cities of the Six Dynasties [Chinese] (Beijing: Cultural Relics Press, 2005); Culture of the Six Dynasties: Archaeology and Discoveries [Chinese] (Beijing: SDX Joint Publishing Company, 2013). 


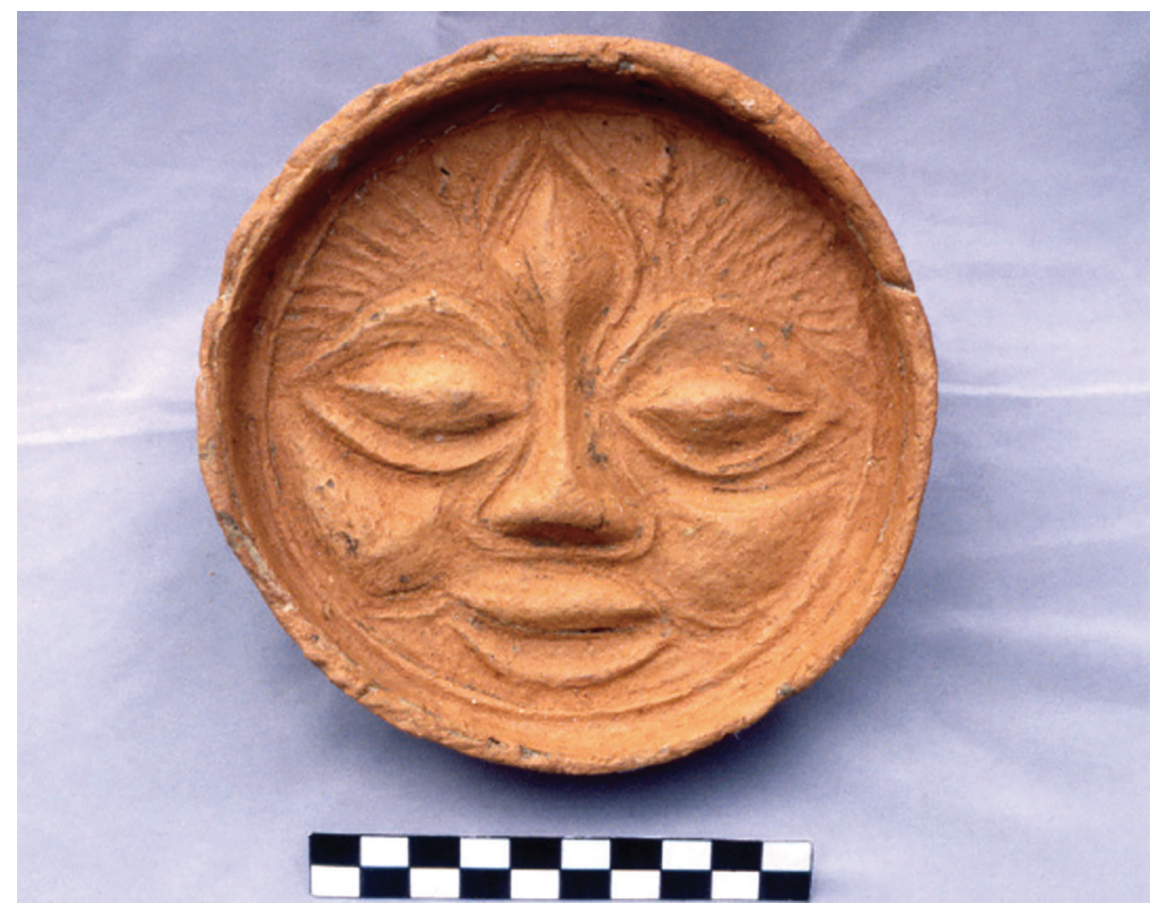

FIGURE 2 End tile with human face decoration, excavated at Hoan Chau, Tra Kieu. PHOTO: YAMAGATA MARIKO.

Northeast and Hoan Chau. The six AMs dates obtained thus far for the eastern ramparts indicate a date range from the latter half of the third century to the first half of the fifth century. ${ }^{15}$ The tentative hypothesis of the excavation team is that the first construction of the rampart most likely occurred in the first half of the fourth century.

In addition to Tra Kieu, eaves tiles decorated with human faces have been found at several other sites, such as Lung Khe (Luy Lau) in Bac Ninh, Tam Tho in Thanh Hoa, My Son in Quang Nam, Co Luy in Quang Ngai, Thanh Cha and Binh Lam in Binh Dinh, Thanh Ho in Phu Yen, and Bang Kheng in Gia Lai. Also, a fragment of such a tile appears in a picture of artifacts found in Po Nagar, Nha Trang. ${ }^{16}$ The presence of roof tiles is significant because they indicate the existence of wooden structures supporting heavy roof tiles, which were

15 Bui Chi Hoang et al., "Excavation at the Eastern Rampart of Tra Kieu in Central Vietnam: A Preliminary View on Its Structure and Date," paper presented at the 2oth Indo-Pacific Prehistory Association Congress, Siem Reap, Cambodia, January 12-18, 2014.

16 Henri Parmentier, Inventaire decriptif des monuments cams de l'Annam, vol. 2 (Paris: Ernest Leroux, 1918). 
generally used as administrative centers, royal palaces, religious temples, and so on. In the case of central Vietnam, the earliest roof tiles appear at Tra Kieu and Go Cam, ${ }^{17}$ which are both situated on a tributary of the Thu Bon River, in the first half of the second century CE. ${ }^{18}$ Prior to the appearance of tiles, the Iron Age sites of the Sa Huynh Culture spread over central Vietnam, but none of those sites had a building with a tiled roof. The Sa Huynh Culture declined by the end of the first century CE, so its fall and the emergence of the earliest settlements at Tra Kieu and Go Cam were quite close in time. ${ }^{19}$

What should be emphasized here is that the earliest tiles in central Vietnam obviously belonged to the East Asian style that had originated in China. Analysis of the fabric and manufacturing technique of the tiles has suggested that they were produced locally. While roof tiles of the East Asian style are found in central Vietnam, Indian-style roof tiles seem to have first appeared in the Oc Eo Culture, an archaeological culture generally assigned to the first kingdom of Funan. ${ }^{20}$ Roof tiles excavated at the Cat Tien site, an ancient religious complex situated between central and southern Vietnam, are very unique. ${ }^{21}$ They belong to neither the East Asian style nor the Indian style.

In northern Vietnam, the East Asian-style roof tiles appeared much earlier at Co Loa, a large-scale citadel situated about 14 kilometers north of Hanoi. The eaves tiles of Co Loa have a rolling cloud pattern that prevailed during the Qin and Han Dynasties in China. The tiles of Co Loa were found in piled

17 Nguyễn Kim Dung, "Di chỉ Gò Cấm và con đường tiếp biến văn hóa sau Sa Huỳnh khu vực Trà Kiệu" (Go Cam Site and Acculturation after Sa Huynh Culture in the Tra Kieu Region), Khảo cổ học (Archaeology) 2005, no. 6 (2005): 17-50; Nguyen Kim Dung et al., "Excavations at Tra Kieu and Go Cam, Quang Nam Province, Central Viet Nam," in Uncovering Southeast Asia's Past, ed. E. Bacus, I. C. Glover, and V. Piggot (Singapore: National University of Singapore Press, 2006), 216-231.

18 Yamagata and Nguyen Kim Dung, "Ancient Roof Tiles Found in Central Vietnam"; Yamagata, "The Early History of Lin-i"; Yamagata, "Tra Kieu during the Second and Third Centuries CE."

19 Yamagata, "The Early History of Lin-i."

20 Hirano Yuko, "Roof Tiles found in the Mekong Delta: With special reference to tiles of the Go Tu Tram site in Oc Eo Site Complex" [Japanese], Research Report of the Japan Society for Southeast Asian Archaeology 6 (2008): 59-66.

21 Lê Đình Phụng, Di tích Cát Tiên Lâm Đồng - Lịch sử và văn hoá (Hanoi: Nhà xuất bản khoa học xã hội, 2007); Bùi Chí Hoàng, "Diện Mạo khu di tích Cát Tiên qua tài liệu khảo cổ học" (The Physiognomy of the Complex of Cat Tien Sites through Archaeological Data), Khảo cổ học (Archaeology) 2008, no. 6 (2008): 47-57; Ota Chikako, Bui Chi Hoang and Yamagata Mariko, "Features and Artifacts of the Cat Tien site, Lam Dong province of Southeastern part of Vietnam" [Japanese], Buddhism Art 319 (2011): 85-118. 
earth layers of the middle ramparts, ${ }^{22}$ and also in a location inside the inner rampart called Den Thuong (Upper Temple), where a bronze casting furnace was revealed, ${ }^{23}$ so they must have been closely related to the early construction of Co Loa. Nishimura shared his opinion on the date of Co Loa with his Vietnamese colleagues, suggesting that the construction and usage of the citadel could be dated from the end of the third century ВСЕ to the first half of the second century BCE. Nishimura also discussed the manufacturing technique of the tiles found at the location called Bai Men, just outside of the outer rampart. ${ }^{24}$ Having compared tiles of Co Loa with those of Nanyue, he concluded that the former could be dated earlier than tiles found at the site of Nanyue Kingdom Palace in Guangzhou.

Concerning eaves tiles decorated with a human face, Chinese archaeologists in Nanjing have assigned these tiles to the Wu Kingdom (222-28o CE). Based on the comparison between Tra Kieu and Nanjing, it is Yamagata's hypothesis that ancient inhabitants of Tra Kieu adopted the Wu motif of human faces to decorate the roofs of their own buildings, and that the same motif was subsequently adopted in other citadels of Linyi, including Co Luy and Thanh Ho. The use of a single motif on decorated eaves tiles manufactured for palaces, temples, and other important buildings in citadels may reflect a kind of alliance of regionally developed centers of Linyi, which can be compared to the political organization of mandalas. ${ }^{25}$

22 Nam C. Kim et al., "Co Loa: An Investigation of Vietnam's Ancient Capital," Antiquity 84 (2010): 1011-1027.

23 Lại Văn Tới, "Khảo Cổ Học Cổ Loa vấn đề và thảo luận" (Archaeology of Co Loa: Data and Discussion), Khảo cổ học (Archaeology) 2008, no. 4 (2008): 73-82; Lại Văn Tới et al., "Kết qủa khai quật di tích đúc mũi tên đồng tại Đền Thượng, Cổ Loa (Hà Nội), năm 2007" (Excavation Results from a Bronze Arrow Head Casting Site at Den Thuong in Co Loa, Ha Noi), Nhũng phát hiện mới về khảo cổ học năm 2007 (New Discoveries of Archaeology in 2007) (Hanoi: Nhà xuất bản khoa học xã hội, 2008), 105-109.

24 Nishimura Masanari and Trần Thị Kim Quý, "Những mảnh ngói của di chỉ Bãi Mèn (Khai quật 2003): phân loại và kỹ thuật chế tạo" (Roof tiles of the Bai Man Site, excavated in 2003: Classification and Manufacturing Technique), Nhũng phát hiện mới về khảo cổ học năm 2005 (New Discoveries of Archaeology in 2005) (Hanoi: Nhà xuất bản khoa học xã hội, 2006), 192-193.

25 Charles Higham, The Archaeology of Mainland Southeast Asia (Cambridge: Cambridge University Press, 1989), 302-304; Yamagata Mariko and Momoki Shiro, "Linyi and Huanwang" [Japanese], in Iwanami Lectures on Southeast Asian History 1: The World of Protohistoric Southeast Asia, ed. Yamamoto Tatsuro (Tokyo: Iwanami Shoten Publishers, 2001), 250-251. 
Archaeologists digging at Nanjing have suggested that the human-face motif could relate to a Chinese folk belief concerning fire prevention. ${ }^{26}$ Nishimura was inclined to support the idea proposed by Vietnamese archaeologists that human faces on eaves tiles at Tra Kieu represent Makala/Kala, an imaginary creature of Hindu mythology. ${ }^{27}$ If the hypothesis that the Wu human-face motif was applied to the eaves tiles of Tra Kieu is correct, the Chinese interpretation seems reasonable. Among the various human faces at Tra Kieu, however, some appear to represent faces of people from the west. The wide variety of faces on eaves tiles found in central Vietnam implies that they might have continued to be produced after they were no longer manufactured in Nanjing, and thus the meaning assigned to the faces might have altered. According to the Nanjing archaeologists, eaves tiles decorated with human faces were replaced by tiles with animal faces in the early fourth century.

Nishimura proposed another account of the development of eaves tiles decorated with a human-face motif. He observed that these tiles are contained in the bottom layers at Lung Khe, assigned to the fourth quarter of the second century CE. ${ }^{28}$ Lung Khe was therefore the place where the oldest tiles with a human face decoration were created, and the diffusion of these tiles might have occurred from Lung Khe to Nanjing, as well as from Lung Khe to Tra Kieu. Also, tiles with a lotus pattern possibly emerged at Lung Khe prior to their appearance at other sites in Vietnam and southern China. Nishimura ascribed this innovation to the spread of Buddhism in Jiaozhi Province of the Eastern Han under the rule of Shi Xie, the powerful governor of Jiaozhi who was supposed to have resided in Lung Khe. Buddhism was then introduced from Jiaozhi to the $\mathrm{Wu}$, followed by the eaves tiles with a human face and those with a lotus. It is difficult, however, to verify this magnificent hypothesis because detailed information on the stratigraphy of the excavated trenches at Lung Khe has not been reported yet, and thus the archaeological context of the recovered tiles remains unknown. Further investigation of the roof tiles of Lung Khe is crucial to clarify the historical significance of this citadel.

Nishimura also discussed the religion practiced in Tra Kieu. Considering the possibility that the human-face motif represented Makala/Kala, and comparing spouted jars called kendis, supposed to have originated in India, that were excavated at Tra Kieu with those of Oc Eo in southern Vietnam, he

26 Wang Zhigao and Ma Tao, "Discussion on Eaves Tiles with Clouds and Those with Human Faces unearthed at Nanjing Daxinggong” [Chinese], Wenwu 2007, no. 1 (2007): 92.

27 Nishimura Masanari, Archaeology and Ancient History of Vietnam (Betonamu no KokoKodaigaku) (Tokyo: Doseisha, 2011), 170.

28 Ibid., 169. 
conjectured that Indian religion was practiced at Tra Kieu. Concerning the issue of so-called Indianization, archaeological materials assigned to Tra Kieu I and II phases of the second and third century CE show less evidence of Indian influence than Chinese. The process of Indianization at the capital of Linyi should be investigated and argued systematically, based on a secure chronological framework. This is one of the reasons why Yamagata and her colleagues decided to carry out excavations at the eastern rampart of Tra Kieu. As mentioned above, the construction of the ramparts may be dated from the fourth century CE, generally regarded as the initial period of Indianization.

In Vietnam, ramparts enclosing ancient citadels have been excavated at several sites, including Co Loa, Lung Khe, Tra Kieu, and Thanh Ho. Section observations and AMS dates, combined with stratigraphy, have shed light on the structure and the date of their construction, although the published information available remains scant.

Comparing the ramparts of Tra Kieu with the northern rampart of Lung Khe, whose stratigraphy was closely observed and described by Nishimura, ${ }^{29}$ some similarities in structure can be pointed out. Excavation of the eastern and southern ramparts at Tra Kieu revealed two brick walls with rammed infill clay layers between them that served as the core structure of the ramparts (Fig. 3). The core is about 3 meters wide, reinforced by an outer structure of clay layers partly containing large pieces of broken bricks. The whole rampart is about 33 meters wide at the bottom.

Nishimura noted that some brick walls, probably part of a core structure, were identified at Lung Khe. These structures may have had characteristics similar to those of Tra Kieu. The construction of ramparts at Lung Khe dates from the middle of the second century CE, according to Nishimura. If that is the case, then the ramparts at Lung Khe were constructed more than one hundred years before those at Tra Kieu. The method of rampart construction at Tra Kieu may have been shaped by northern influence.

\section{Hoa Chau Citadel in Thua Thien Hue Province}

The ancient site of the Hoa Chau Citadel is now confined entirely within the area of three villages, namely Thanh Trung, Kim Doi, and Thuy Dien of Quang Thanh commune (Quang Dien District, Thua Thien Hue Province). As early as the sixteenth century, this citadel was mentioned by Duong Van An in O Chau Can Luc, and later on it was featured in Le Quy Don's Phủ Biên

29 Ibid., 158-160. 


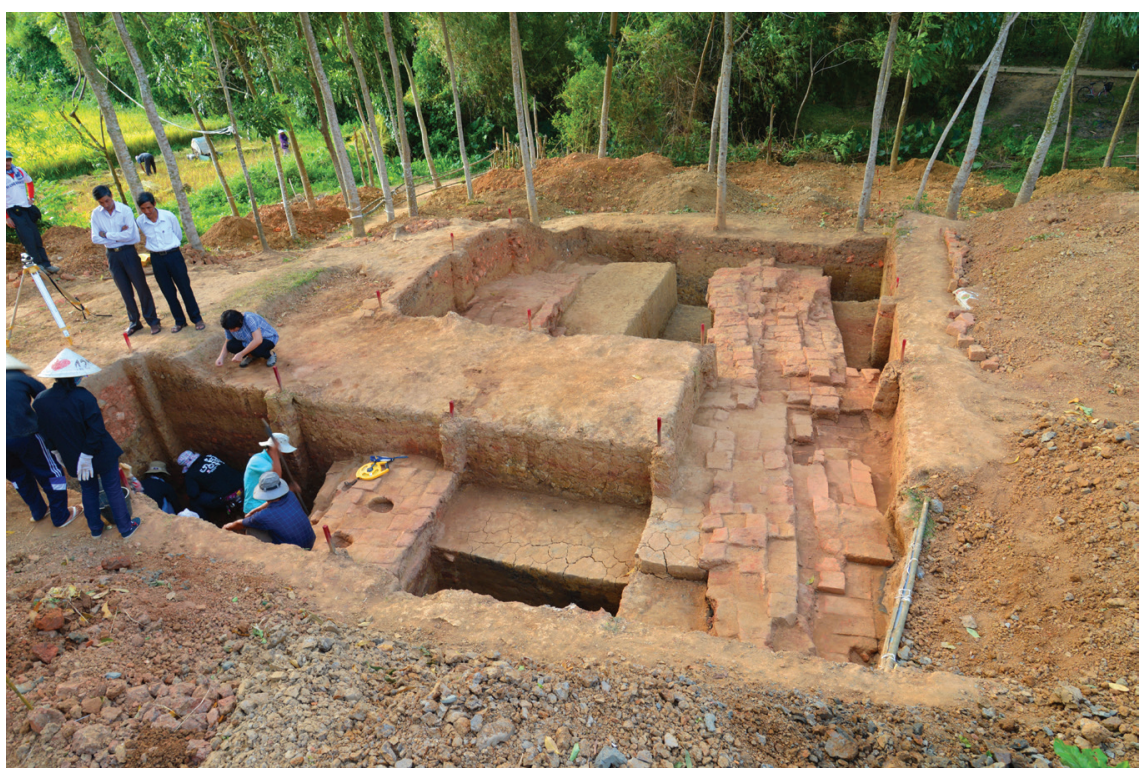

FIGURE 3 Excavation on the eastern rampart, Tra Kieu, viewed from the south. PHOTO: NGUYỄN HOÀNG BÁCH LINH.

Tạp Lục ${ }^{30}$ and Quốc sử quán triều Nguyễn's Đại Nam Thực Lục. ${ }^{31}$ Since then, many attempts have been made to study the Hoa Chau Citadel; however, the scope and structure of the citadel have not been accurately determined, and its date and owner are uncertain. Answering these questions was the main goal of the excavations at the Hoa Chau Citadel from 2007 to 2012 by the History Department of the Hue University of Sciences and Kansai University (Japan), in which the late Dr. Nishimura Masanari participated.

The Hoa Chau Citadel lies on the lower course of the Huong River. The southern rampart is about 1 kilometer from the Sinh confluence, about 400 meters from the Bo River/Dan Dien, and 6 kilometers from the Thuan An estuary; the northeastern rampart is approximately 2.5 kilometers from the Tam Giang Lagoon. Surrounding and inside the outer citadel are the two rivers of Thanh Trung and Tien Thanh, connecting with the Bo River and the Tam Giang

30 Lê Quý Đôn, Phủ biên Tạp lục (Miscellaneous Chronicles of the Pacified Frontier) (Hanoi: Nxb Văn hóa Thông tin, 2006), translated into Vietnamese by the Institute of Historical Study.

31 Quốc sử quán triều Nguyễn, Đại Nam nhất thống chí (Dai Nam Comprehensive Encyclopedia), vol. 1 (Hue: Nxb Thuận Hóa, 2006), translated into Vietnamese by the Institute of Historical Study. 
Lagoon. These two rivers have some straight segments that are also equal in width, especially the segment of the Thanh Trung River within the outer citadel, and the segment bordering Luy Thanh south of the Tien Thanh River. The authors assume that these two rivers include artificial segments where ancient people built a dyke to connect the Bo River and the Tam Giang Lagoon.

The surrounding area is a plain only approximately $1-1.5$ meters above sea level. Currently, the surrounding area comprises paddy fields, as it is flooded regularly during the rainy season. If the Loi Citadel in the hilly Long Tho area (presently belonging to Thuy Bieu Ward, Thuy Xuan Ward, and Phuong Duc Ward of the city of Hue) is located at the position known as the first water gate on the Huong River (the Tuan confluence), the Hoa Chau Citadel should be located in the plain, close to the sea and Tam Giang Lagoon, at the site of the second water gate, also known as the "place where all water flows gather" because it lies close to the Sinh confluence, where the Huong River and the Bo River meet up. This shows that the Hoa Chau Citadel occupied a very favorable location for guarding the coastal region. ${ }^{32}$

In order to draw the structure of the ramparts accurately, eighty concrete pillars were set up in the citadel to form a geodetic grid system, and a GPS geodetic device was used to measure topography. Satellite images and maps of land parcels in this area, combined with survey results and field drawings, were used to reconstruct the plan of the Hoa Chau Citadel (Fig. 4). The Hoa Chau Citadel clearly includes two walls bounding the outer citadel and the inner one (also known as the Cut Citadel). The outer citadel is roughly rectangular, and some segments are not connected (the gaps probably represent the citadel's entrances). The northern rampart, which runs from northeast to southwest, is nearly 1,700 meters in length and includes two unconnected segments and many mounds. At the southwest corner of the northern rampart, just outside of the outer citadel, there are two tiny ramparts. The outside wall is L-shaped and measures 685 meters in length.

The southern rampart measures over 2,00o meters in length. The western segment runs east-west while the eastern segment runs northeast-southwest. Between the western and eastern segments a short segment (ca. 110 meters) is preserved. To the south of this segment stands a short rampart, with a length of about 340 meters. In general, the southern rampart is narrower than the northern one. In the southeast corner of the southern wall there are two layers of short wall (about 350 meters and 410 meters in length respectively). The eastern wall (bordering Kim Doi village) and the western wall (bordering Tay Ba market,

32 Lê Đình Phụng, "Thành Hóa Châu trong lịch sử”(Hoa Chau Citadel throughout History), Thông tin Khoa học \& Công nghệ (Information of Science and Technology) 1 (Hue: Thua Thien Hue's Department of Science, Technology and Environment, 1998), 64. 


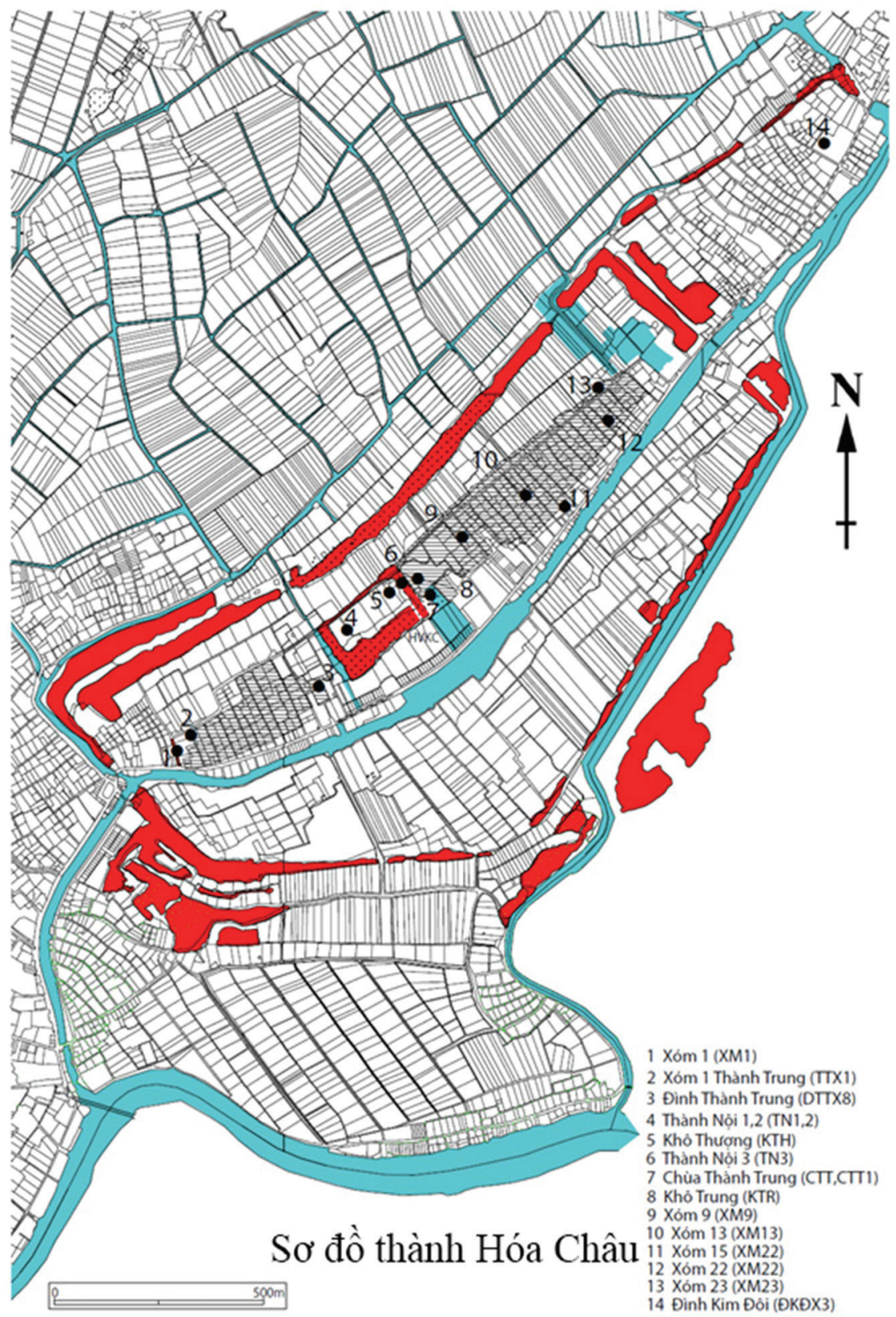

FIGURE 4 Hoa Chau Citadel. Walls and ramparts are indicated in red. DRAWING: NISHIMURA MASANARI. 
Quang Thanh commune) are each comprised of two unconnected segments located on either side of the Kim Doi River. The two segments of the western rampart extend over 500 meters in length while those forming the eastern wall measure 600 meters. The total perimeter of the outer citadel (including the unconnected segments) is over 4,700 meters long.

The inner citadel is rectangular in shape and located in the heart of Thanh Trung village, north of the Kim Doi River. Both the northern and southern ramparts are aligned parallel to the northern wall of the outer citadel. As they are preserved today, the southern rampart is wider than the northern one and they are equal in length, roughly 234 meters. The western and eastern ramparts respectively measure 147 meters and 137 meters in length. The total perimeter of the inner citadel is about $75^{\circ}$ meters. After scraping the section of the fifth hole $(2 \times 10$ meters $)$ excavated by the Institute of Archaeology in 1997 near the southeast corner of the inner citadel, we realized that the stratigraphy of the rampart did not show multiple layers of different soils, as is frequently the case with citadel walls constructed in north Vietnam, for example at Co Loa and Luy Lau. Instead, the soil layers in the wall are mainly composed of sandy soil that is yellow in color. At the bottom of the wall, stones ranging from 30 to 50 centimeters in size were placed on sandy ground (Fig. 5).

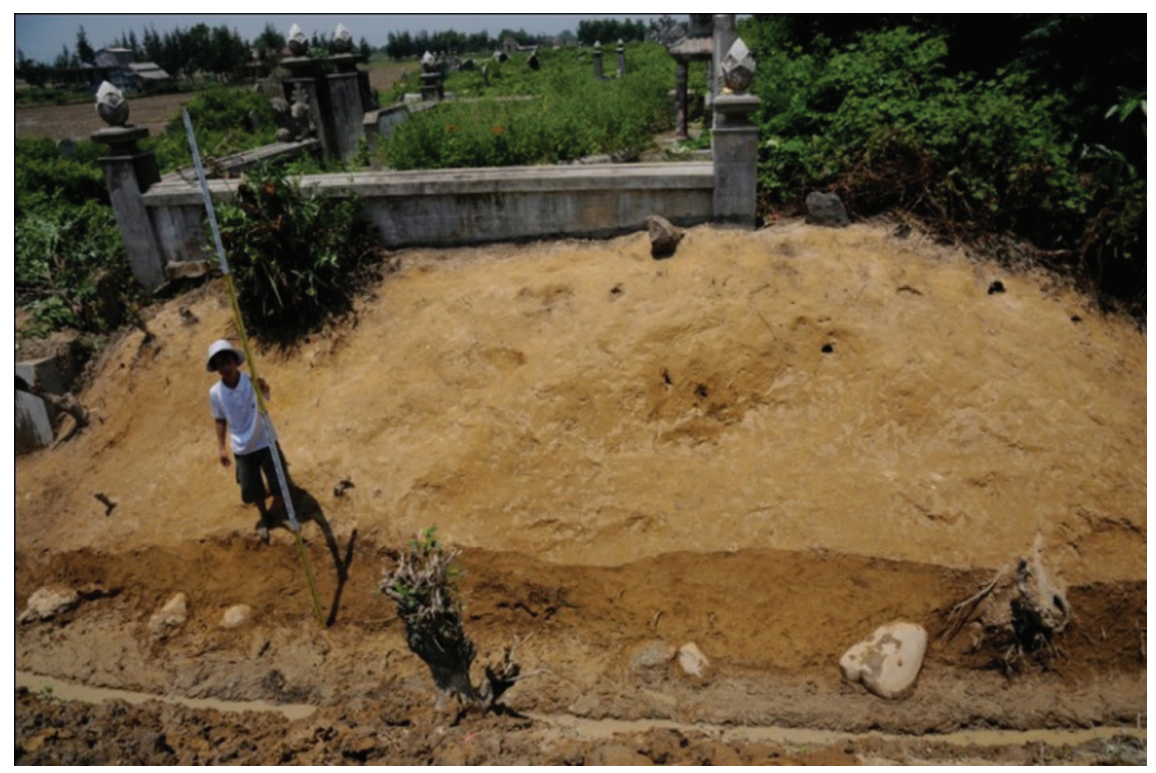

FIGURE 5 Rampart of inner citadel. PHOTO: NISHIMURA MASANARI. 
During the survey, we discovered what appeared to be a walled-in area to the northeast of the outer citadel, which we tentatively identified as the "northern citadel." It corresponds to the residential area of the modern village of Kim Doi. The northern citadel is aligned on a northeast-southwest axis and was probably connected with the wall of the outer citadel in the north. There are some gaps in the northern wall of the northern citadel. Outside of the eastern wall of the outer citadel runs a parallel rampart, similar to the eastern rampart in length and width. This parallel rampart was presumably the western wall of the northern citadel. A water canal probably ran between these two walls, serving as a moat. We estimated the total perimeter of the walled-in area to be about 1,770 meters. ${ }^{33}$

The Hoa Chau Citadel was surrounded by a system of deep and wide moats that connected it with the Bo River, the Huong River, and the Tam Giang Lagoon, as well as the East Sea, and thus it played an important role in water traffic. The moat system also provided drainage, preventing the citadel from flooding during the rainy season. In key areas, wooden poles were buried in rows next to each other along the edge of the wall to reinforce it (Fig. 6). In front of and inside the citadel ran the Thanh Trung River and the Tien Thanh River. The river and moat system entered the citadel through six water gates.

Archaeological excavations show that construction mainly occurred from the ninth to the early tenth century and that afterward the inner citadel and the area north of the inner citadel continued to be used until the twelfth-thirteenth century (Figs. 7a-b, 8, 9, and 10a). During this period there were a number of fires, possibly caused by war. In this period the inner citadel was likely located in a swampy area, as lakes, ponds, and rivers occupied many areas both inside and outside of the outer citadel. Champa-period objects are not so abundant within the inner citadel but appear to be abundant to the north, which suggests that the inside of the inner citadel was not the residential area during the second phase (Tran Dynasty period) and that the residential area was located north of the inner citadel (Figs. 11-13).

Considering the large size of this citadel, the number of artifacts belonging to the Champa period are few in number. Taking into account this fact as well as the citadel's location and its ancient environment, the Hoa Chau Citadel does not appear to conform to the model of other citadels in north Vietnam. Probably a small number of people resided inside the citadel and the residential

33 Nishimura Masanari and Nguyễn Văn Quảng, "Nghiên cứu Khảo cổ học thành cổ Hóa Châu" (Archaeological Study in Hoa Chau Citadel), Kỷ yếu Hội nghị Thông báo kết quả nghiên cứu Khu vực thành Hóa Châu: Khảo cổ học và hiện đại (Abstracts of the Conference for the Study of the Hoa Chau Citadel Area: Archaeology and Modernity), Thừa Thiên Huế, September 2013 . 


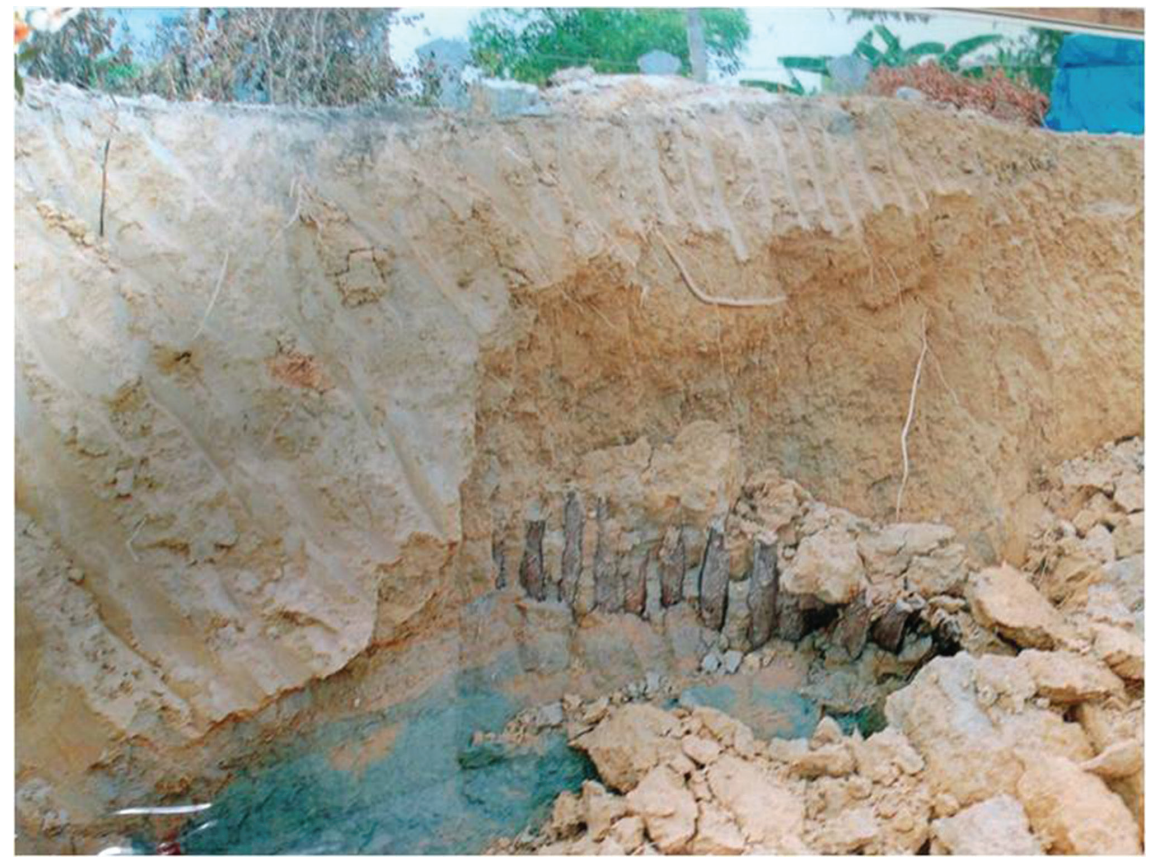

FIGURE 6 Wooden stakes at outer citadel. Pното: ĐÀO LÝ.

area was not large. This suggests something about the function of the citadel: if the town did not contain a large population, then during the Champa period the Hoa Chau Citadel was probably a military or transportation center.

The excavation of the citadel yielded a much denser archaeological record from the time of the Tran Dynasty. The second phase of the Hoa Chau Citadel probably started in the fourteenth century. During this period, the walls of the citadel were filled with soil and solid monuments were built both inside and outside of the inner citadel. During the Ho Dynasty in the early fifteenth century, these activities were more vigorous and continued into the second half of that century. The $\mathrm{TN}_{3}$ trench shows indications that by the mid-fifteenth century a wall had been built on the foundation of the inner citadel from northwest to southeast (Figs. 14, 15, 16a-b, 17, 18). The ceramic evidence shows that residential activity increased in the sixteenth century, and especially from the seventeenth century onward (Fig. $10 \mathrm{~b}-\mathrm{c}$ ). In the modern villages of Thanh Trung and Kim Doi, residential areas are located within the outer citadel, but this was a later development. During the first period of occupation (the seventeenth and eighteenth centuries), the residential area was certainly not as large as it is today. 

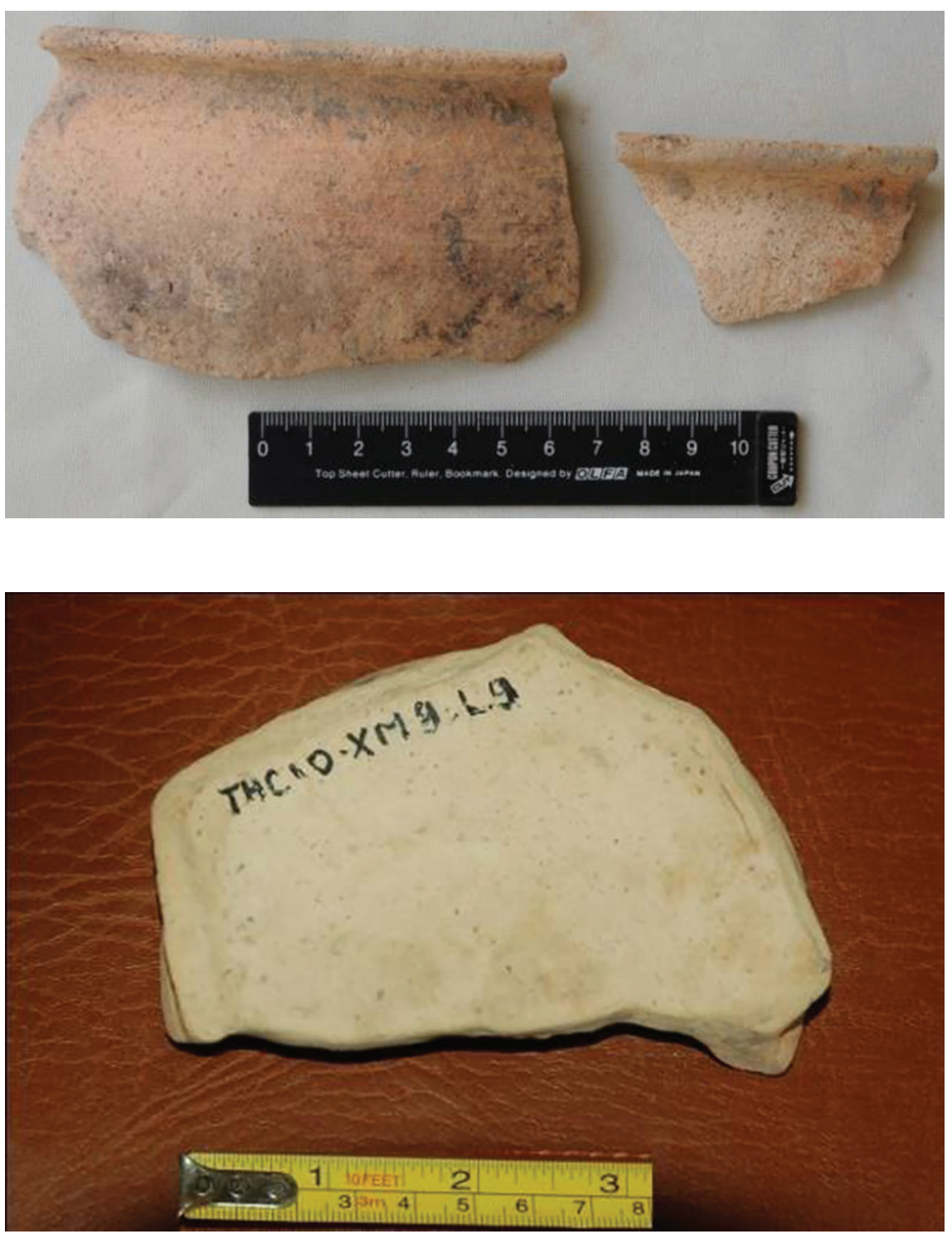

FIGURE 7A-B Champa pottery. PHOTO: NISHIMURA MASANARI. 

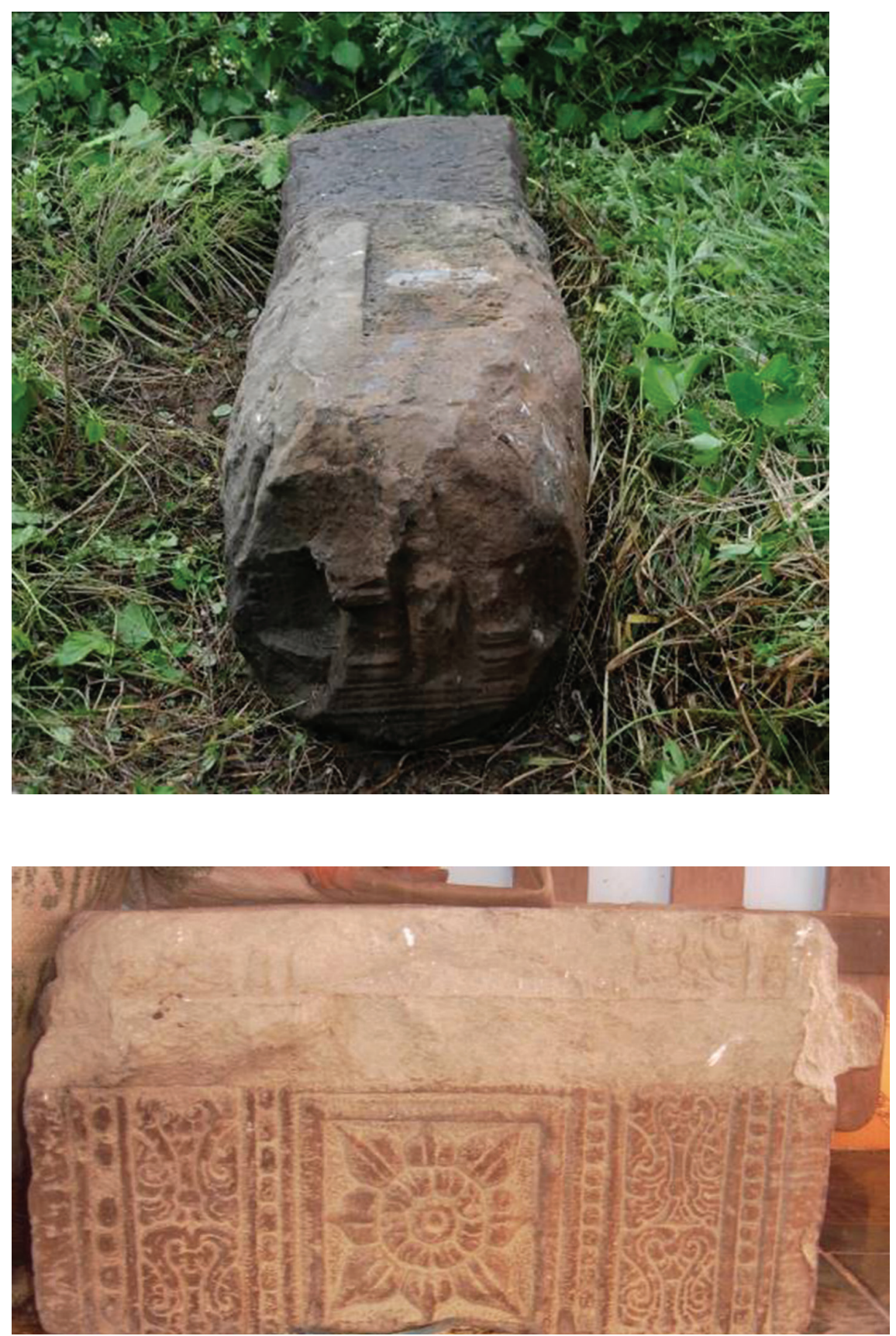

FIGURE 8A-B Champa sculptures in the area of Hoa Chau Citadel. PHOTO: NGUYỄN VĂN QUẢNG. 


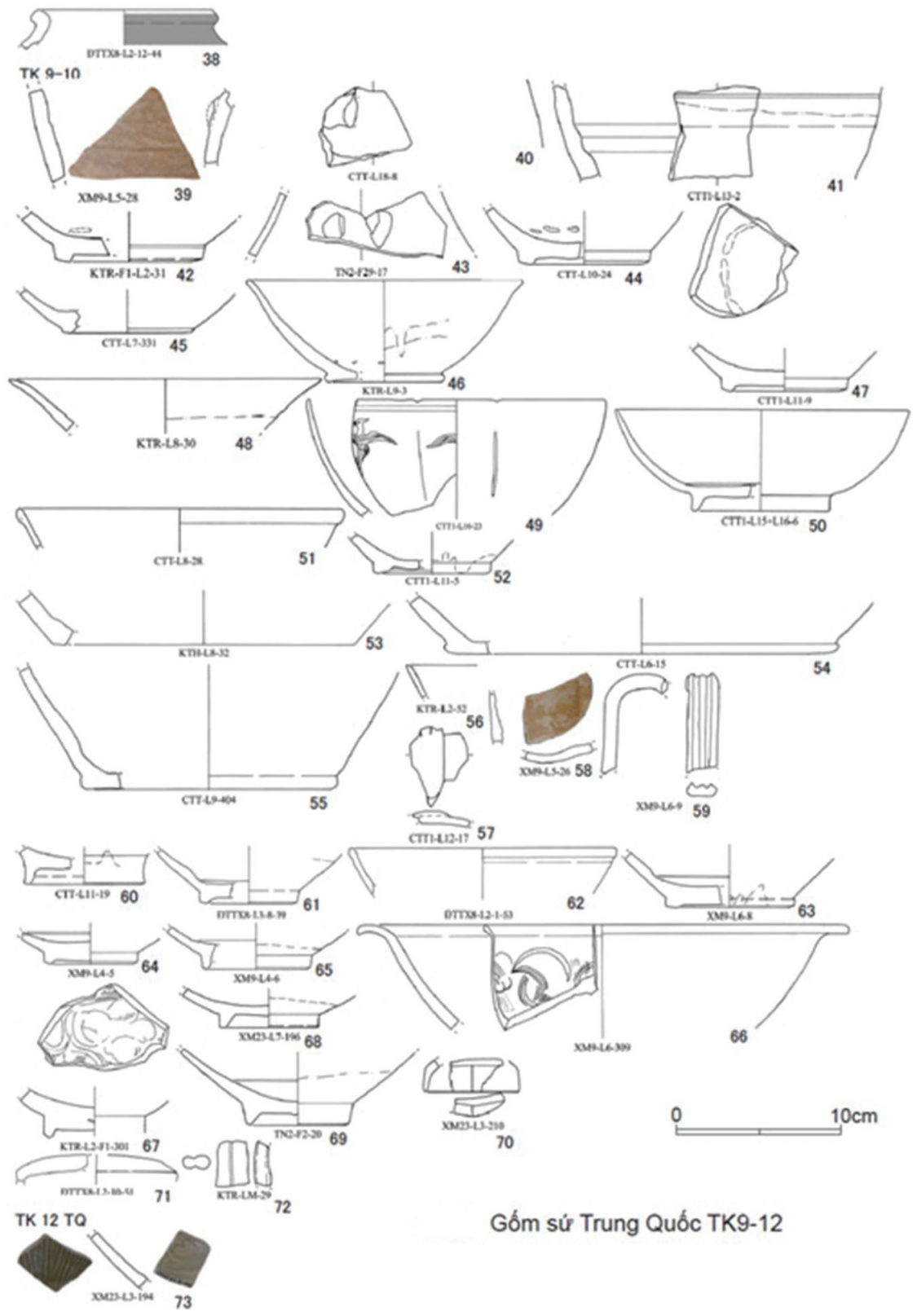

FIgURE 9 Profiles of Chinese vessels found in the Hoa Chau Citadel. DRAWINGS: NISHIMURA MASANARI. 

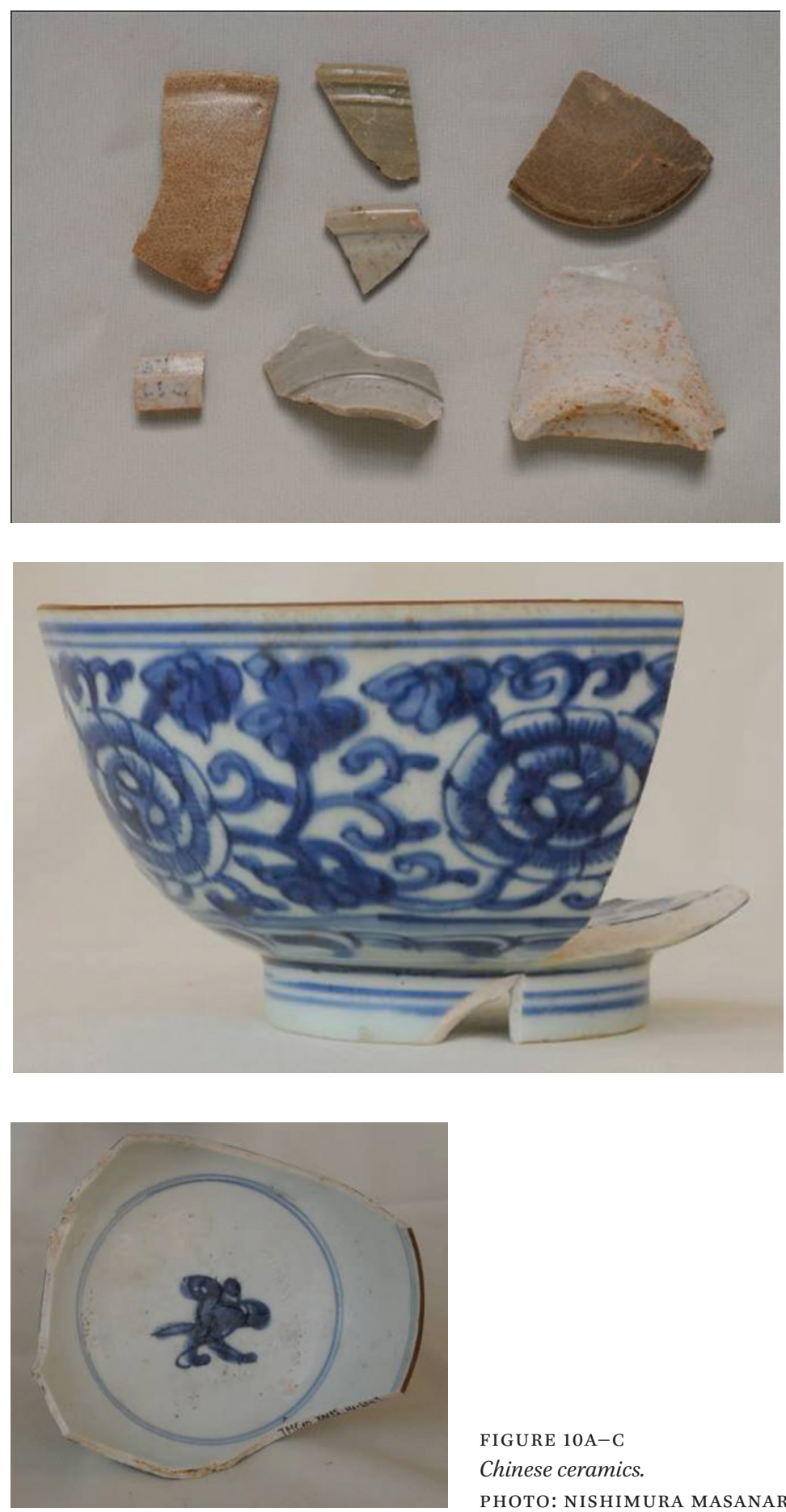

FIGURE 10A-C

Chinese ceramics.

PHOTO: NISHIMURA MASANARI.

ASIAN REVIEW OF WORLD HISTORIES 5 (2017) 70-105 Dohlod from Brill.com04/26/2023 01:58:23AM 


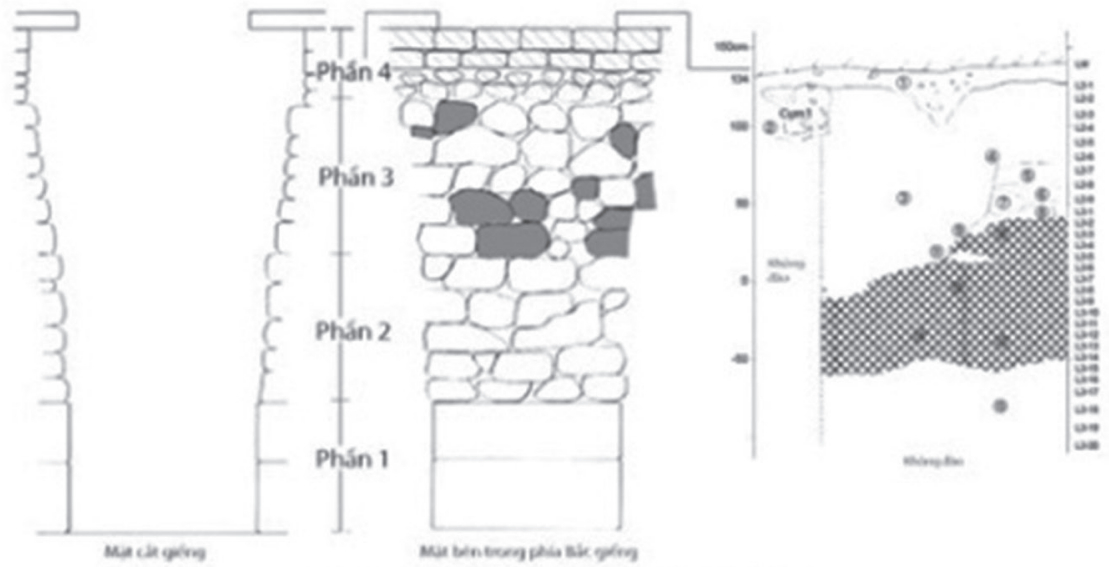

Giêng cổ và mặt cắt của TTX1
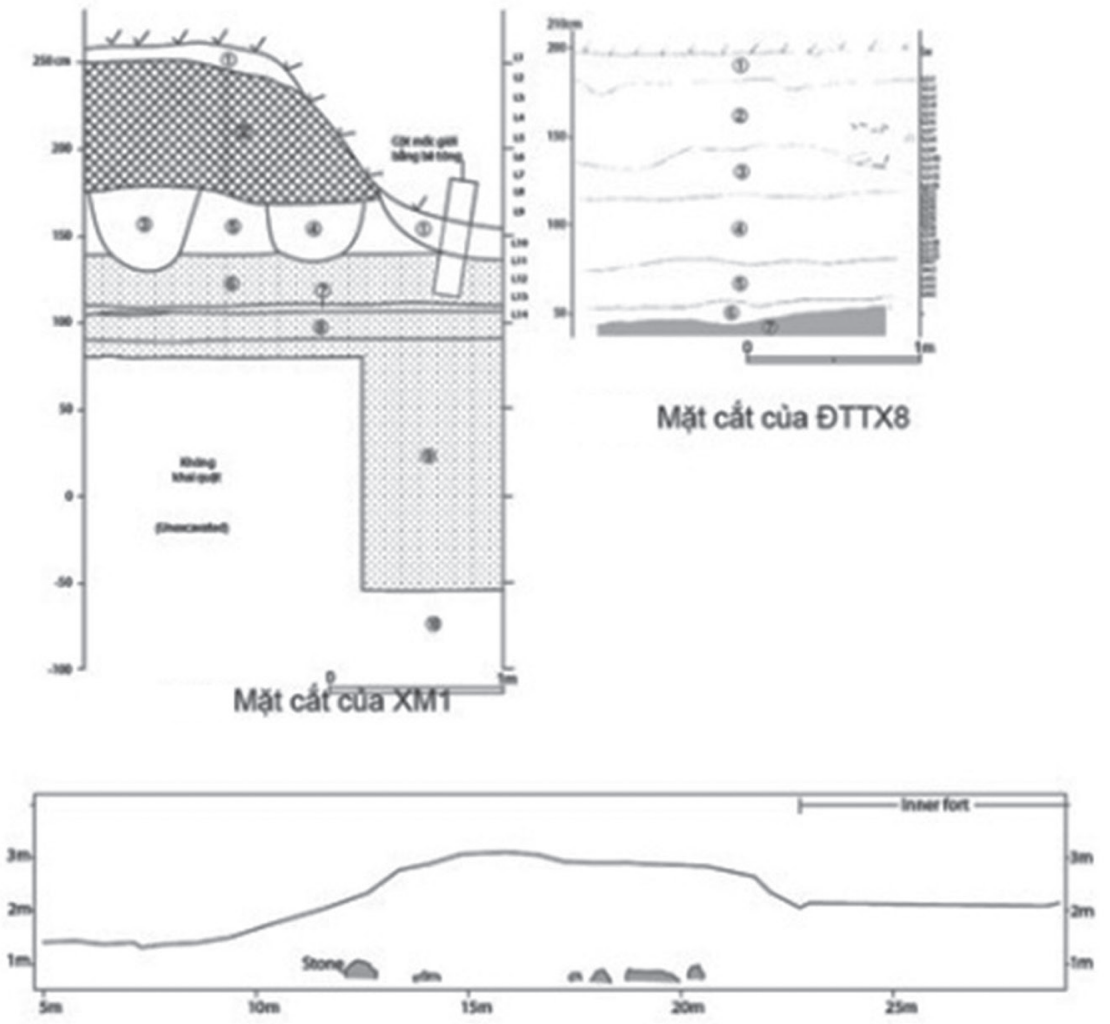

Mặt cát cùa Thành Nội

FIGURE 11 Sections of excavated sites at the Hoa Chau Citadel (TTXI, XM1, DDTTX8, layer of inner citadel). 


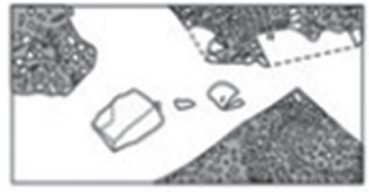

Bình diện (trái) và mặt cất (phải) của hớ thám sát Khô Trung
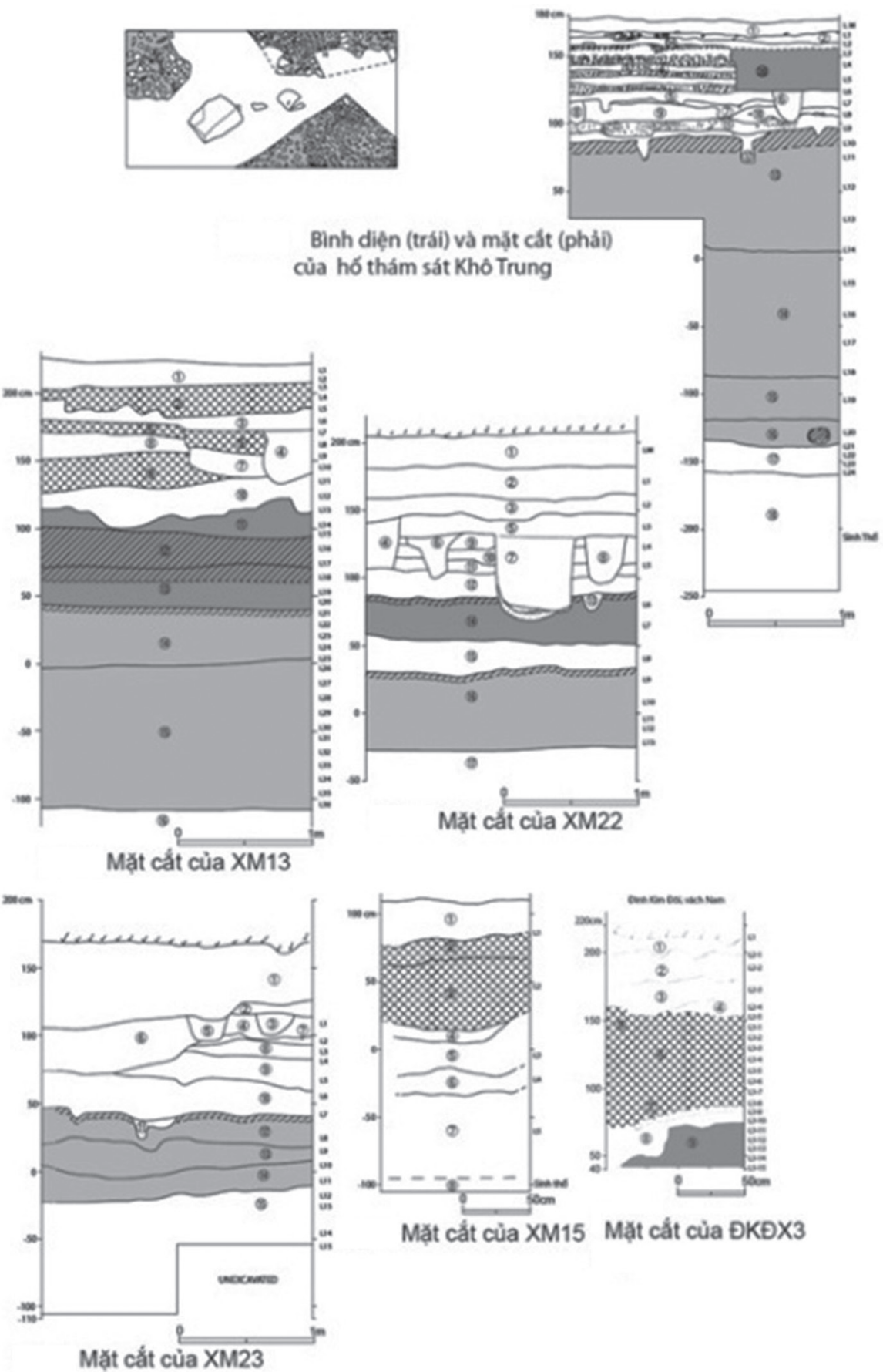

Mặt cắt cùa XM15 Mặt cắt cùa

FIGURE 12 Sections of excavated sites at the Hoa Chau Citadel (KhoTrung, XM13, XM22, XM23, $\left.X M_{15}, \oplus K Ð X_{3}\right)$. 

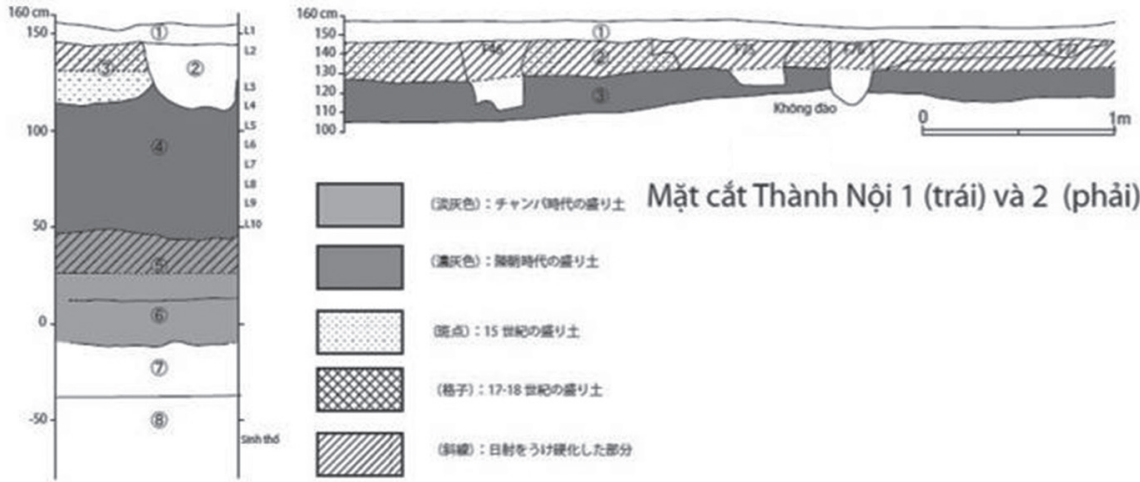

प

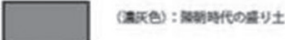

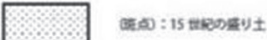

(197) : 17.18

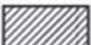

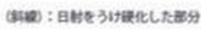

FIGURE 13 Sections of inner citadel 1 (left) and 2 (right) at the Hoa Chau Citadel.

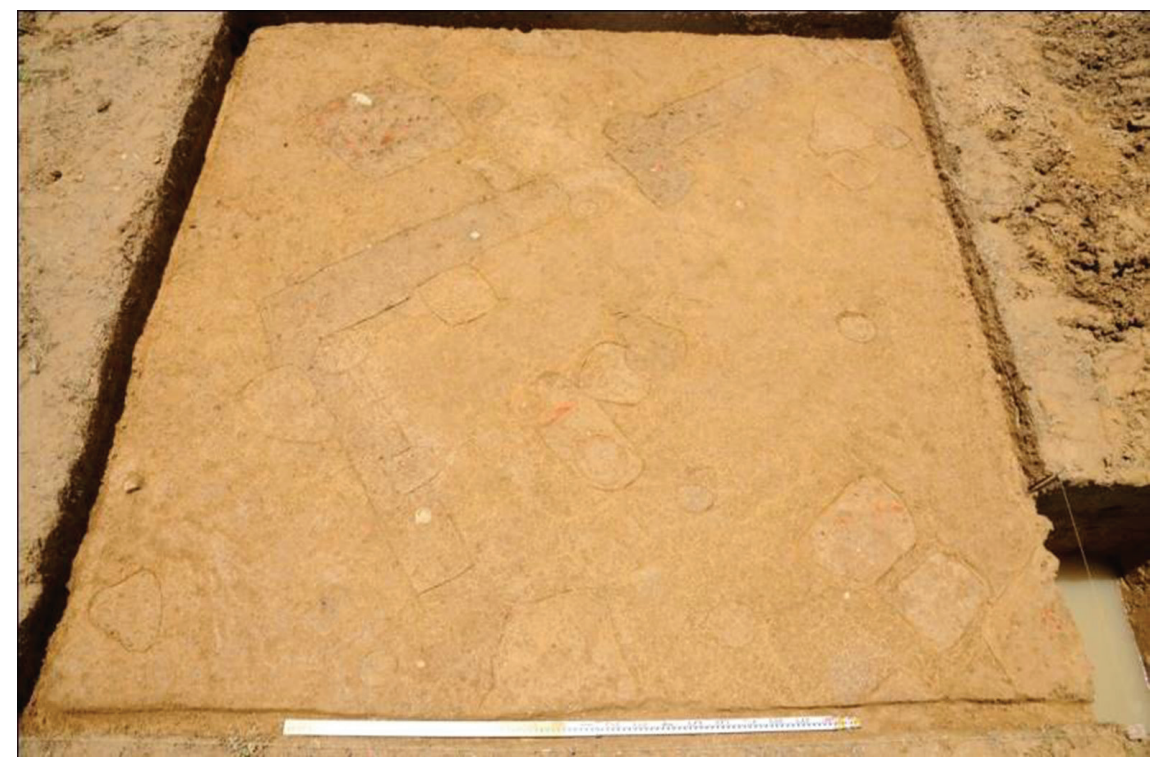

FIGURE 14 TN2 trench.

PHOTO: NGUYỄN VĂN QUẢNG. 

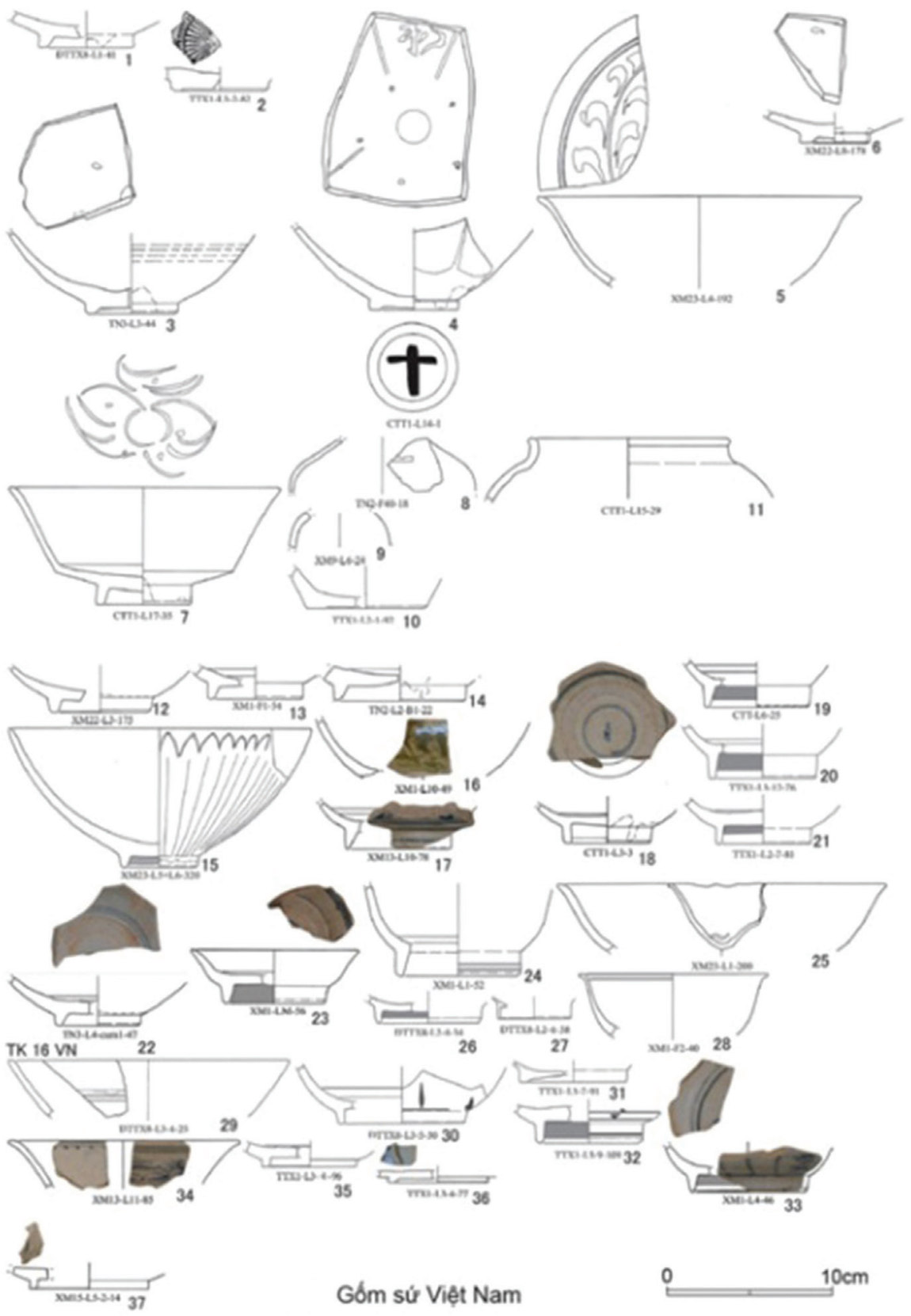

FIGURE 15 Profiles of Tran and Le Dynasty vessels found in the Hoa Chau Citadel. DRAWINGS: NISHIMURA MASANARI. 

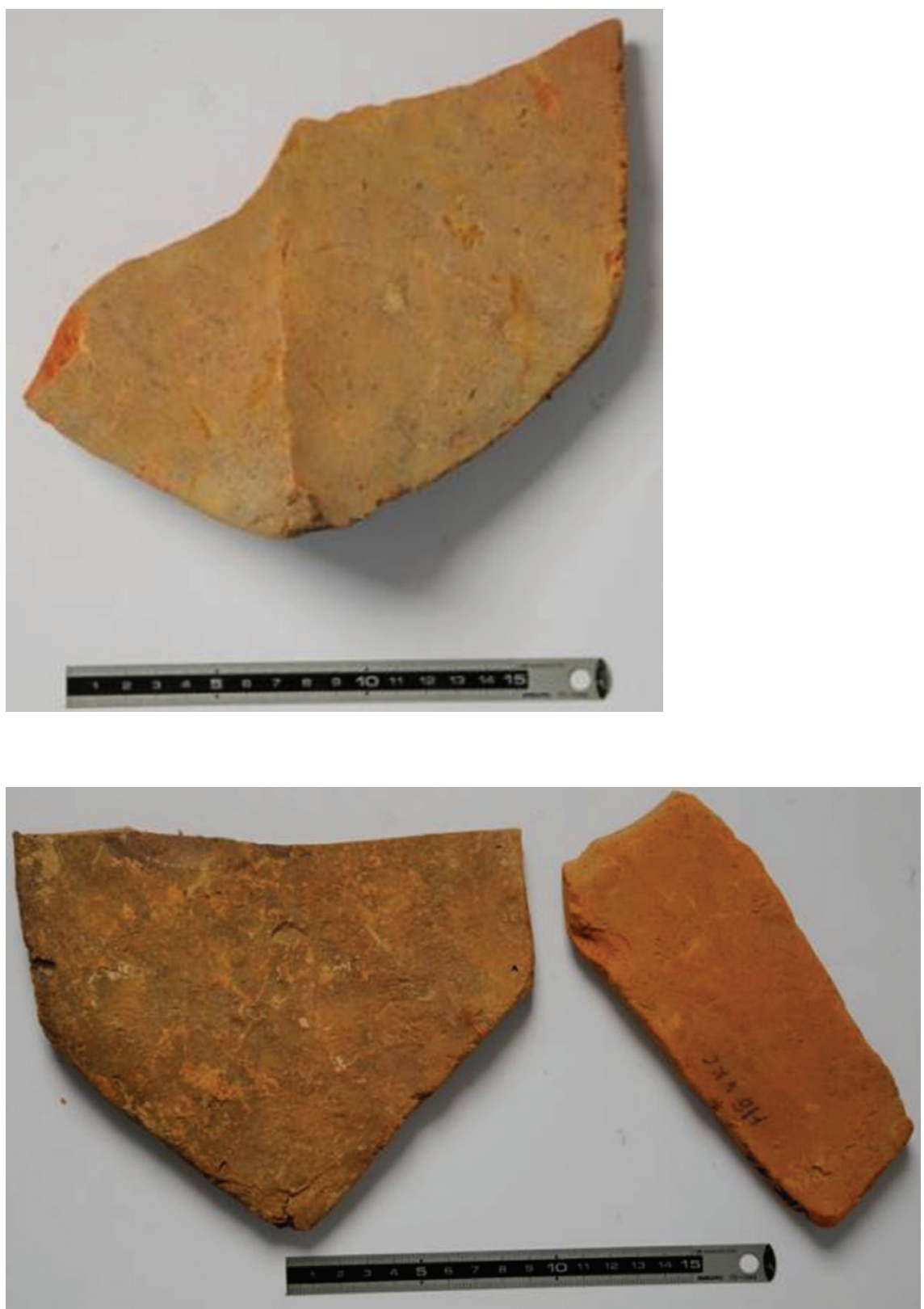

FIGURE 16A-B Tran Dynasty roof tiles (14th century). PHOTO: NISHIMURA MASANARI. 


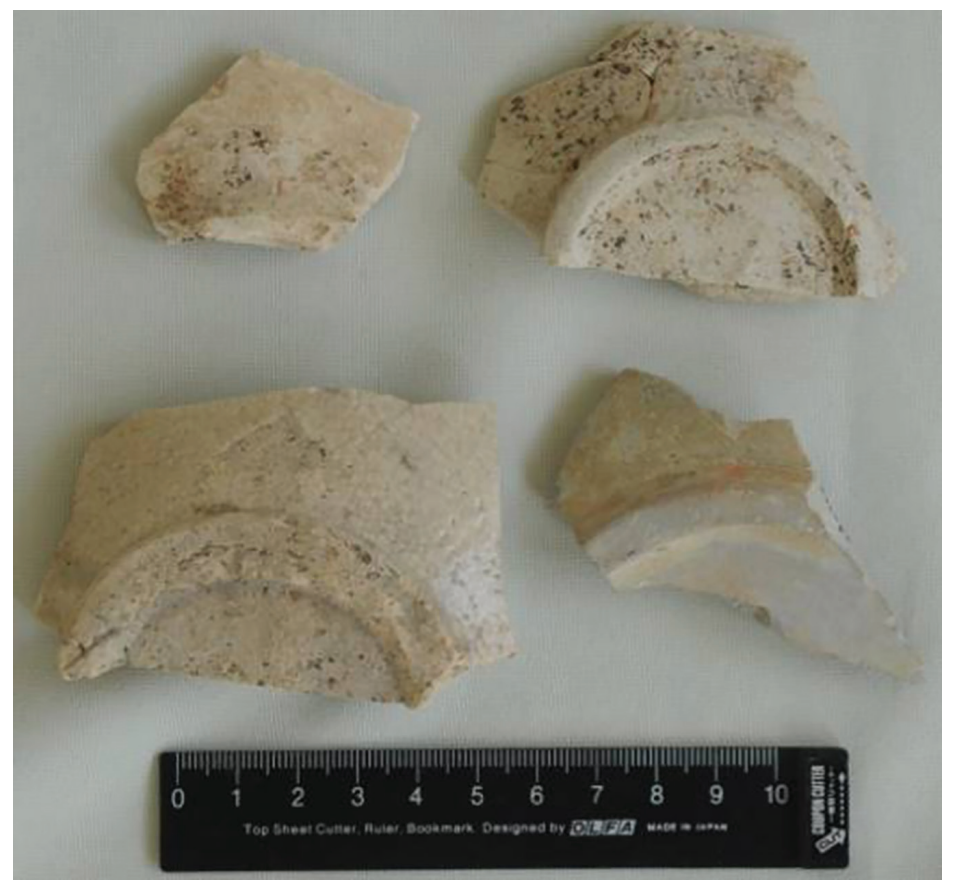

FIGURE 17 Tran Dynasty ceramics (14th century). PHOTO: NISHIMURA MASANARI.

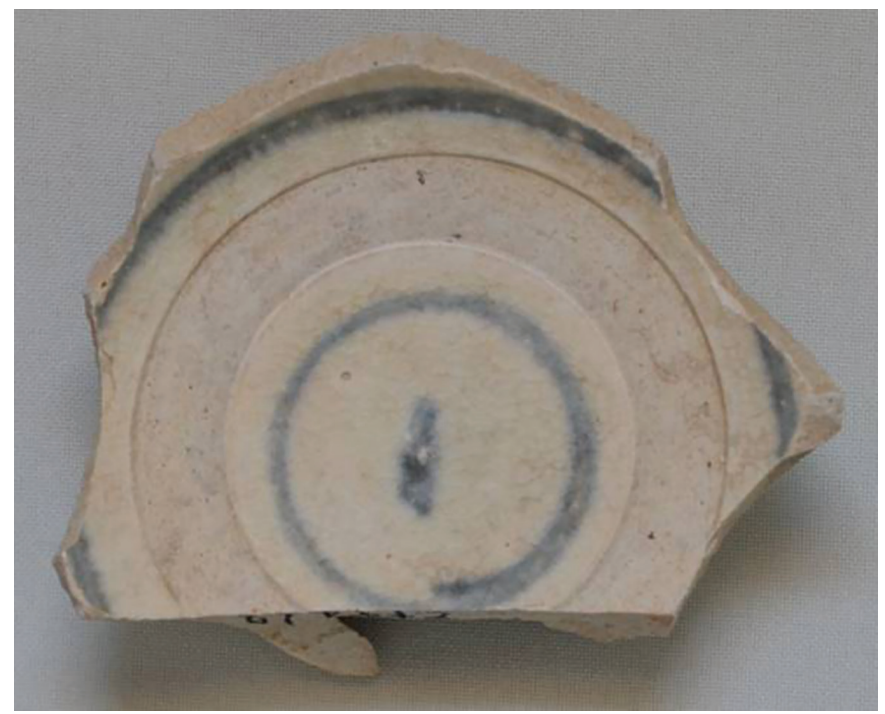

FIGURE 18 Le Dynasty ceramic fragment (15th-16th century). PHOTO: NISHIMURA MASANARI. 
Although the Hoa Chau Citadel shares some similarities with other earthen citadels, the structure and composition of its walls display their own Champa characteristics that distinguish them from citadels in northern Vietnam (Figs. 4, 5). The Hoa Chau Citadel also has features that distinguish it from other Champa citadels, as it has two or three parallel ramparts at the southwest corner of the outer citadel. Notably, outside of the northeastern wall of the outer citadel there was another area enclosed by a surrounding wall (the northern citadel). This feature shows that the Hoa Chau Citadel was more like a water citadel, with both an offensive and defensive military advantage, or like a military citadel positioned close to the sea. ${ }^{34}$

\section{Cha Ban Citadel and the Emergence of Nagara Vijaya in the Twelfth Century}

The Cha Ban Citadel (also known as Do Ban Citadel) is located at Nhon Hau commune, on the left bank of the Kon River in An Nhon District, Binh Dinh Province, and it is basically regarded as the last capital citadel of classical mandala Champa (Fig. 19). Vietnamese historical writings contain only scattered references to this citadel. According to Đại Việt Sử ký Toàn thư, the Cha Ban Citadel severely suffered from a military attack led by King Le Thanh Tong of Dai Viet in 1471. From that moment onward, the Cha Ban Citadel surrendered its role as the political capital of "independent" Champa. Not until the late eighteenth century, during the Tay Son period, would this citadel be reused once again as the political and military center of a new dynasty in Vietnamese history. Đại Nam Nhất thống chí records this citadel under the name "the old Cha Ban (citadel)" and notes that it was once "the national capital of the ancient Champa kingdom," with a circumference of thirty miles.

In the early twentieth century, H. Parmentier published a number of important records in his monumental work Inventaire descriptif des monuments cams de l'Annam. According to Parmentier, the Cha Ban Citadel was one of the largest military structures of the ancient Champa "kingdom." He described it as a rectangle-shaped citadel, about 1,400 meters long on the north-south side and 1,100 meters long on the east-west side. Le Dinh Phung in a recent report

34 Ủy ban Nhân dân tỉnh Thừa Thiên Huế, Địa chí Thừa Thiên Huế (Phần Dân cư và hành chinh) (Chorography of Thua Thien Hue, Living Area and Administration) (Hue: Nхв Thuận Hóa, 2013), 174. 


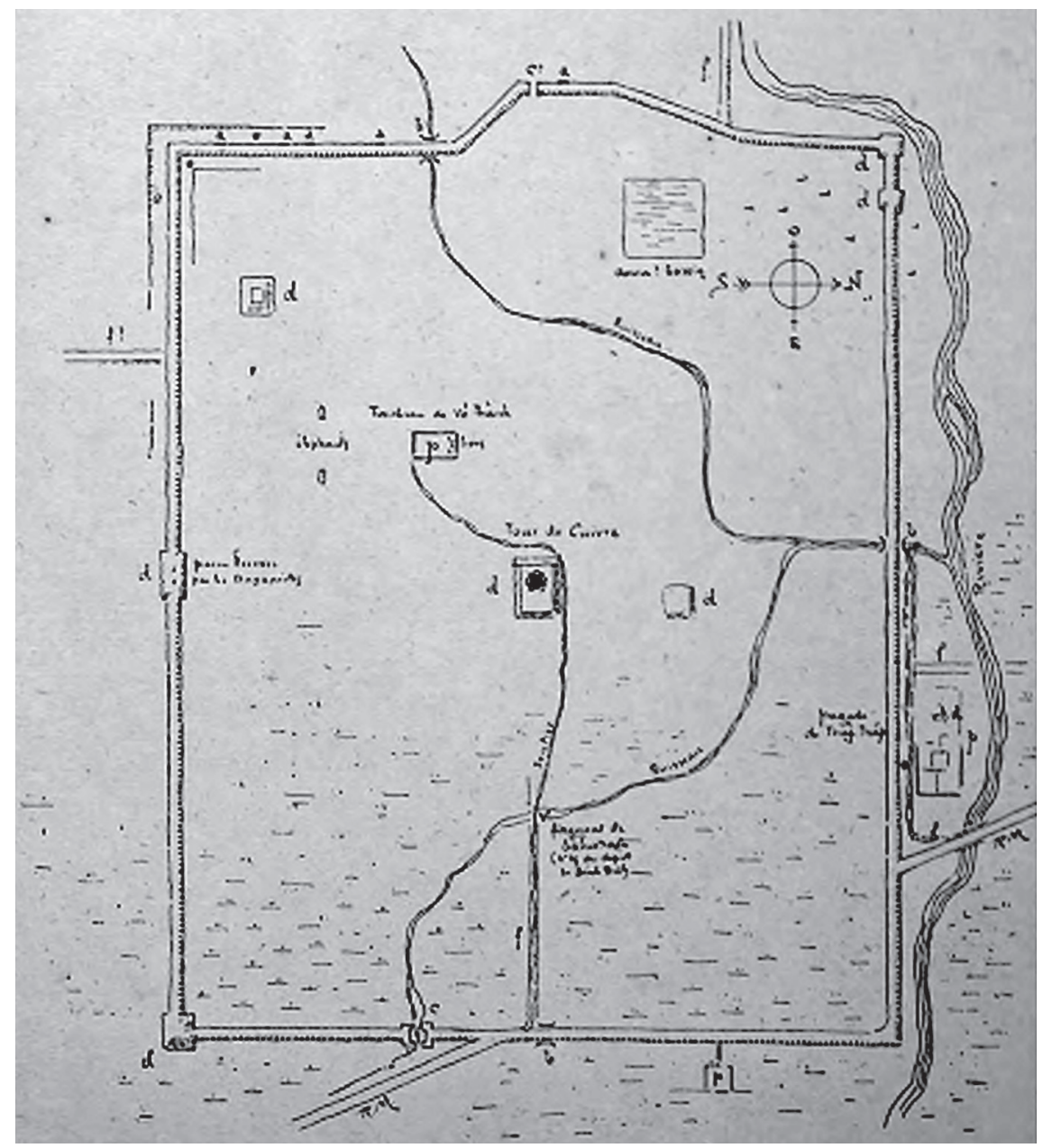

FIGURE 19 Drawing of Cha Ban Citadel. ${ }^{35}$

provides more detailed measurements of the Cha Ban Citadel..$^{36}$ According to Le Dinh Phung, the lengths of the four main ramparts are 2,188 meters (south), 2,038 meters (north), 1,654 meters (east), and 1,610 meters (west). A segment of

35 Henri Parmentier, Inventaire descriptif des Monuments Cams de L'Annam: Planches d'après le relevé et les dessins de l'auteur, Publications de l'École française d'Extrême-Orient 11 (Paris: L'École française d'Extrême-Orient, 1918), plate XLIX.

36 Lê Đình Phụng, Di tích văn hóa Champa ở Bình Định (Champa Relics in Binh Dinh Province) (Hanoi: Nhà xuất bản khoa học xã hội, 2002). 


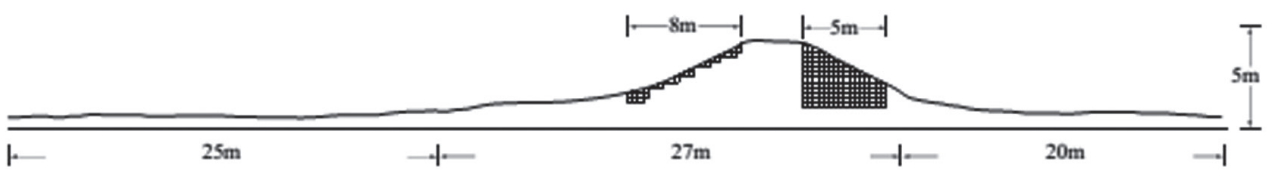

FIGURE 20 Drawing of the southern rampart of Cha Ban Citadel. ${ }^{37}$

the southern rampart (Fig. 20) that was dug out slightly to the west for the irrigation works was built of large laterite blocks ( 0.8 meters long, 0.4 meters wide, and 0.23 meters thick). These blocks were placed next to each other. In order to create stability for the wall surface, fragments of roof tiles were inserted between the laterite blocks. Roof tiles, which had been found in great numbers at the Go Sanh ceramic kilns south of the Cha Ban Citadel, were frequently used in Champa structures. Since the Cha Ban Citadel was not far from the Go Sanh ceramic kilns, the roof tiles found at the southern rampart were probably made at these kilns along with other Go Sanh ceramics. This suggests that the walls of the Cha Ban Citadel, or at least the southern wall, were built at the same time as the ceramic kilns in the south, around the thirteenth-fourteenth century. ${ }^{38}$ On the other hand, a segment of the eastern rampart that was leveled for construction purposes in 2000 was made of earth, without any trace of laterite or bricks. ${ }^{39}$

In August 2012, a team led by the late Dr. Nishimura that included Nguyen Van Quang, Do Truong Giang, and Tran Van Quyen undertook surveys at two ancient Champa citadels in Binh Dinh Province, including the An Thanh Citadel south of the Kon River and the Cha Ban Citadel north of the river. The results of this survey were presented briefly in Dr. Nishimura's last publication. ${ }^{40}$ According to him, the most important features of the Cha Ban Citadel are the areas of earthworks (or extended areas) outside of the north, west, and south ramparts. The perimeter of the main area is about 7,520 meters. If we add the length of the extended area in the west, the total perimeter is about 9,260 meters. The size of the main area is 3.67 kilometers $^{2}$, the extended area in the west measures 0.67 kilometers $^{2}$, and the total area of the main area plus the extended areas in the west, south, and north is 4.68 kilometers $^{2}$. The Cha Ban Citadel is thus the second largest citadel in Vietnam, following the Thang Long Citadel. ${ }^{41}$

39 Ibid.

40 Ibid.

41 Ibid., 111-113. 


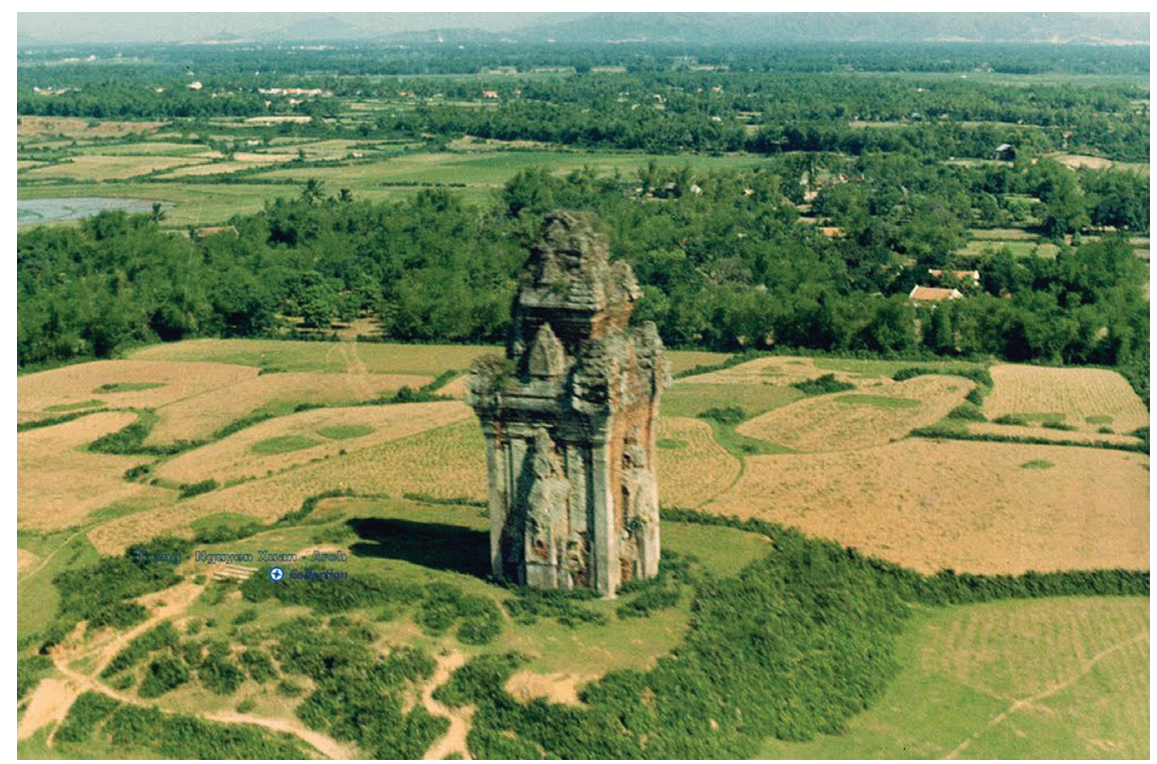

FIGURE 21 Canh Tien Tower within Cha Ban Citadel, aerial photo, 196o. ${ }^{42}$

Unlike most other Champa citadels, where virtually all structures were destroyed, a Champa tower still stands at the center of this citadel—Canh Tien Tower (Fig. 21). Phillipe Stern guessed that Canh Tien Tower, along with two other temples at Thu Thien and Thoc Loc, also in Binh Dinh Province, was built in the thirteenth century. ${ }^{43}$ Boisselier, however, suggested on the basis of archaeological details and decorations at Canh Tien Tower that this tower exemplified the Thap Mam style of art, dating from the first half of the twelfth century to the end of the first quarter of the thirteenth century. ${ }^{44}$

A number of Champa sculptures have also been found within the citadel area and interestingly most of them continue to be worshipped by Vietnamese communities. Not far from Canh Tien Tower, for instance, there are two Champa stone elephants that are among the biggest stone elephants in the entire corpus of ancient Champa art (the male elephant is 2 meters tall and the female 1.7 meters tall). According to Boisselier, these two stone elephants, like Canh Tien Tower, were products of the Thap Mam art style and were undoubtedly

\footnotetext{
42 Photograph hosted at http://www.panoramio.com/photo/68454467.

43 Phillipe Stern, L'art du Champa (ancien Annam) et son evolution (Toulouse: Douladore, 1942).

44 J. Boisselier, La statuaire du Champa (Paris: EFEO, 1963).
} 


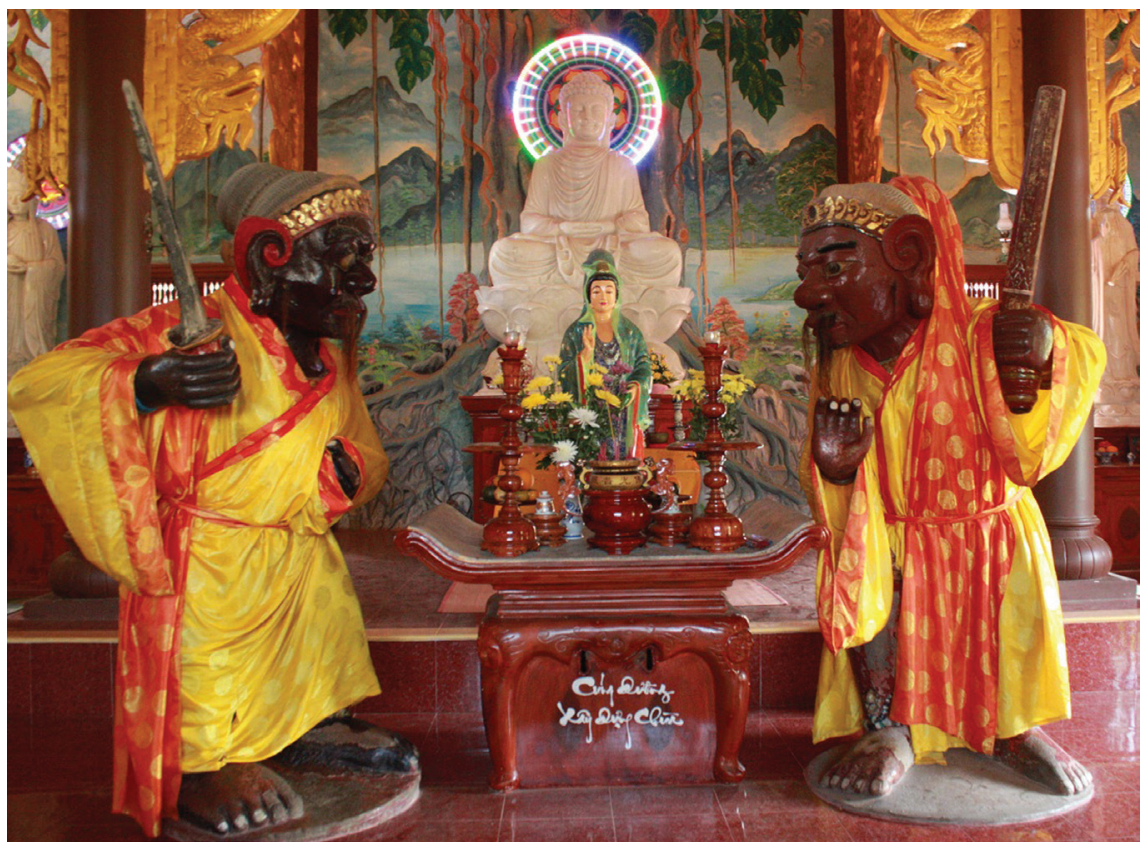

FIGURE 22 Stone Dvarapalas at Nhan Son Pagoda. 45

influenced by Khmer art in the second half of the twelfth century. ${ }^{46}$ At Nhan Son Pagoda, located within the Cha Ban Citadel area, there are still two giant stone Dvarapalas, each of which is about 2.5 meters high and carved from a single block of stone (Fig. 22). These two are among the largest stone Dvarapalas in Champa sculpture. H. Parmentier, who conducted a survey at this site in the early twentieth century, suggested that another Champa structure had been built there but was subsequently destroyed..$^{47}$ These two Dvarapalas are associated with the Thap Mam art style (from the twelfth to the thirteenth century) ${ }^{48}$ and are among the last Buddhist Dvarapalas of Champa sculpture. ${ }^{49}$

In 1997, Vietnamese archaeologists conducted an excavation of an ancient well at the center of the Cha Ban Citadel. They found 471 artifacts of all kinds,

45 See "Chuyện huyền bí về 2 pho tượng khổng lồ Ông Đỏ, Ông Đen" (Mythical Stories about Two Giant Statues of Ông Đỏ and Ông Đen," Dân Trí, http://dantri.com.vn/van-hoa/ chuyen-huyen-bi-ve-2-pho-tuong-khong-lo-ong-do-ong-den-785563.htm.

46 Boisselier, La statuaire du Champa, 288-289.

47 Parmentier, Inventaire decriptif des monuments cams de l'Annam, vol. 1.

48 Boisselier, La statuaire du Champa, 271.

49 Ngô Văn Doanh, Thành cổ Chămpa (Ancient Champa Citadels) (Hanoi: Nhà xuất bản thế giới, 2011), 189-193. 
including many different forms such as bowls, cups, jars, and plates, both glazed and unglazed (Figs. 23-25). At the lowest layer of the pit (5-6 meters deep) were found Chinese ceramic shards, including blue and white ceramics, white Ding porcelain, and celadons from Dehua, Jingdezhen, and Longquan kilns. All these Chinese ceramics are believed to be products of the Yuan and early Ming dynasties (from the thirteenth to the fourteenth century). Along with Chinese ceramics, Vietnamese ceramics were recovered from this site as well, together with Champa ceramics at a depth of 3-4 meters. Twenty-three fragments of Vietnamese ceramics were recorded and determined to be products of the Hop Le and Chu Dau kilns in northern Vietnam during the fourteenth and fifteenth centuries. ${ }^{50}$

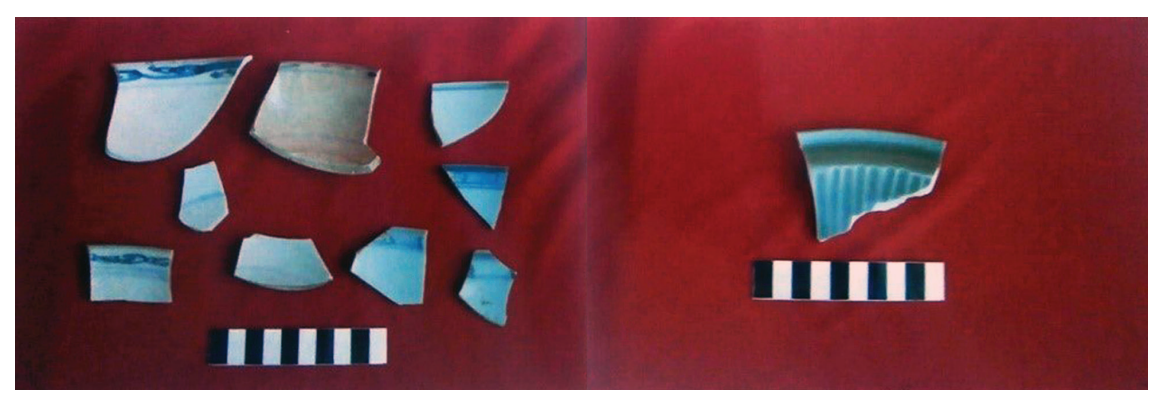

FIGURE 23 Chinese ceramics found within the Cha Ban Citadel. 51

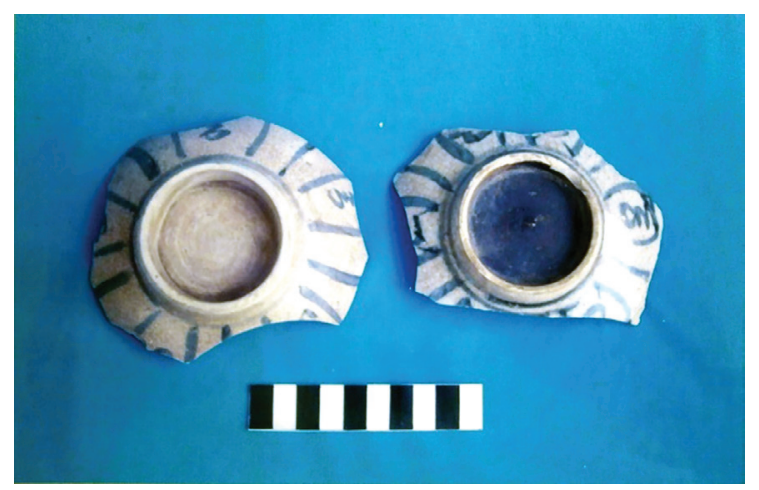

FIGURE 24

Vietnamese blue and white ceramics found within the Cha Ban Citadel. 52

50 Đinh Bá Hòa, Báo cáo Khai quật Gò Nghĩa địa - thôn Bả Canh, An Nhơn, Bình Định (Report on Archaeological Excavation at Go Nghia dia-Ba Canh Commune, An Nhon District, Binh Dinh Province), Binh Dinh General Museum, 1997.

51 Đinh Bá Hòa, Báo cáo Khai quật Gò Nghĩa địa.

52 Ibid. 


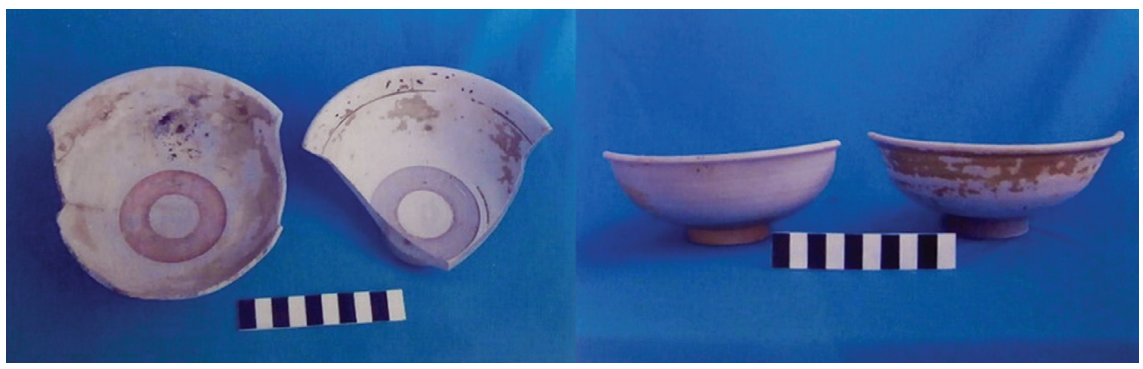

FIGURE 25 Go Sanh ceramics found within the Cha Ban Citadel. ${ }^{53}$

According to G. Maspero, the capital of Champa changed at the end of the tenth century, which saw the emergence of Vijaya, which replaced Indrapura in the north. Maspero assumed that the citadel of "Phat The" (Foshi) mentioned in Vietnamese records was that of Vijaya in Binh Dinh. Recently, however, scholars have deconstructed Maspero's interpretation and suggested that it was only in the twelfth century that Vijaya became an important political center of Champa. Michael Vickery, who is one of the most vigorous of Maspero's critics, assumes that the term "Vijaya" has been misunderstood as both a name and a location, leading to a misinterpretation of the historical narrative by Maspero and other colonial scholars. ${ }^{54}$ Vickery argues that the "Phat The" citadel recorded in Vietnamese sources before the twelfth century was in fact associated with the Dong Duong sanctuary and the Cham nagara in Quang Nam Province. ${ }^{55}$ Vickery's argument is backed by archaeological findings and inscriptions showing that nagara Vijaya only became important in the middle of the twelfth century. All the inscriptions from the end of the tenth century to the end of the eleventh century were in Quang Nam, Nha Trang, and Phan Rang (all of which were part of other nagaras), and not a single inscription was found in Vijaya/Binh Dinh Province during this period. ${ }^{56}$

Beginning in the twelfth century, Champa inscriptions regularly mention a newly established nagara/bhumi of Vijaya in modern Binh Dinh and Phu Yen provinces. Bhumi Vijaya was home to many extraordinary chiefs/rulers

53 Ibid.

54 Michael Vickery, "Champa Revised," in The Cham of Vietnam: History, Society and Art, ed. Tran Ky Phuong and Bruce M. Lockhart (Singapore: National University of Singapore Press, 2011), 385 .

55 Ibid., 389 .

56 Ibid., 392. 
who gradually became rivals and competitors challenging the supremacy of Champa rulers in nagara Amaravati (in the north) and nagara Kauthara (in the south). The three twelfth-century inscriptions $\mathrm{C}_{17}, \mathrm{C}_{101}$, and $\mathrm{C}_{30 \mathrm{~A}}$ all mention the life and career of the famous King Sri Jaya Harivarmadeva, who was born in Vijaya (uran ratna bhumi vijaya) and was then invited to be king of nagara Champa by people of Panduranga. ${ }^{57}$ Interestingly, these three inscriptions were erected in three different geographical positions stretching from the north (My Son in Amaravati) to the south (Panduranga). Jaya Harivarman was the king who made extensive efforts to connect bhumi Vijaya in the coast with rulers and people of mountainous areas (known as karats in inscriptions). It is likely that a political alliance was formed between bhumi Vijaya, nagara Panran, and Khmer troops in an attempt to fight against and gradually replace nagara Amaravati during the twelfth century. ${ }^{58}$

Doubtless, before the emergence of a predominant political center in mandala Champa, there had been a regional polity in this area that probably recognized the patronage and influence of nagara Amaravati. The political center of this regional polity was probably located at the An Thanh Citadel (or Thành Cha) on the southern bank of the Kon River. Archaeological surveys show that the An Thanh Citadel was built as a political center before the twelfth century. ${ }^{59}$ In its structure and scale the An Thanh Citadel resembles the Tra Kieu Citadel in the north and the Thanh Ho Citadel in the south, the latter two belonging to the early period of Champa civilization. The Cha Ban Citadel may have been built and subsequently developed as the new political and religious center of

57 Inscription $\mathrm{C}_{17}$, also known as the Batau Tablah/Đá Nẻ Inscription, dated 116o/61 CE, mentions a king, Jaya Harivarman I, who was also referred to as His Majesty Sri Jaya Harivarmadeva, Prince Sivanandana, and Ratna Bhumi Vijaya. Inscription C1o1, found in My Son and dated to the twelfth century, also mentions Jaya Harivarman I, whose personal name was Ratnabhumivijaya. Karl-Heinz Golzio, Inscriptions of Campa, based on the editions and translations of Abel Bergaigne, Etienne Aymonier, Louis Finot, Edouard Huber and other French scholars and of the work of R. C. Majumdar (Aachen: Shaker, 2004), 161-162, 166-168.

$5^{8}$ Do Truong Giang, "Champa and the East Asian Maritime Commerce from the 1oth to the 13th Centuries," Advancing Southeast Asian Archaeology 2013: Selected Papers from the First SEAMEO SPAFA International Conference on Southeast Asian Archaeology, ed. Noel Hidalgo Tan (Bangkok: SEAmeo spafa Regional Centre for Archaeology and Fine Arts, 2015), 373-409. See also Do Truong Giang, "Diplomacy, Trade and Networks: Champa in the Asian Commercial Context (7th-1oth Centuries)," Moussons 27 (2016): 59-82.

59 Lê Đình Phụng, Di tích văn hóa Champa ở Bình Định, 231-239; Ngô Văn Doanh, Thành cổ Chămpa (Hanoi: Nhà xuất bản thế giới, 2011), 157-178. 
nagara Vijaya after Jaya Harivarman ascended the throne in the second half of the twelfth century.

Based on the surviving structures within and surrounding the Cha Ban Citadel, Ngo Van Doanh suggests that the citadel was created on the model of the holy capital city of the gods at Mount Meru. Canh Tien Tower was situated at the center of the citadel while the king and his royal court resided in the western side of the citadel. As at Angkor Thom, the four ramparts and the surrounding moats and rivers of Cha Ban reflected the holy mountains and oceans of the universe, and thus Cha Ban was "a holy city serving as a religious, political and cultural center rather than an urban center." 60 The late Dr. Nishimura noted another crucial role of the Cha Ban Citadel, i.e., its military role in warding off threats from Champa's neighbors-Dai Viet in the north and Angkor in the west. Probably from the thirteenth century onward, when Cha Ban became the political, religious, and military center, the former citadel of An Thanh likely served as an important center of ceramic production in nagara Vijaya, given the presence in that region of a dense network of Go Sanh ceramic kilns.

\section{Concluding Remarks}

Nishimura pointed out some features that characterize Champa citadels. He described the geographical setting of Champa citadel sites as he surveyed each citadel and compared it with the others in terms of spatial structure and manner of construction. Based on his comparative studies, Nishimura suggested that these citadels were often located close to a river. Tra Kieu, Thanh Loi, Hoa Chau, Cha Ban, and Thanh Ho all have extended areas at the corners or outer sides of their ramparts. Therefore, Nishimura argued that they all had a defensive function. In particular, the Cha Ban Citadel had larger extended areas near the ramparts and was perhaps more oriented toward defense than the other citadels. With respect to the chronology of the Champa citadels, Nishimura explained that the political center of the Quang Nam-Thu Bon area in the fifth to the tenth century was located at the Chiem Son site, which had no defensive wall. The Tra Kieu, Ho, and Co Luy citadels possibly functioned as citadels during an earlier period of Champa history. However, from the fifth to the eighth century, there was apparently no citadel in the Thu Bon River basin of Quang Nam Province where, as the inscriptions suggest, one of the political centers

6o $\quad$ Ibid., 199 . 
of mandala Champa was located during this period. Recent archaeological advances in this region suggest that the Chiem Son site in Duy Xuyen District functioned as the political center in this period. At this site, a citadel without defensive ramparts did exist. This is an interesting fact to consider when thinking about the power structure of mandala Champa. From the fourteenth to the fifteenth century, there were only two citadels in all of mandala Champa: Cha Ban and An Thanh. Dr. Nishimura argued that mandala Champa finally became an "integrated society" in this period. This may be confirmed by the scale of the Cha Ban Citadel and the absence of extended areas outside its ramparts.

In addition to his extensive fieldwork at Hoa Chau in Hue, Nishimura conducted surveys at Thanh Loi in Hue, Tra Kieu in Quang Nam, Thanh Ho in Phu Yen, and An Thanh (Thanh Cha) and Cha Ban (Thanh Hoang De) in Binh Dinh. ${ }^{61}$ It seems that he paid special attention to the spatial plan of those citadels. His comparative studies and insights on the citadels and forts of central Vietnam ${ }^{62}$ will hopefully inspire contemporary archaeologists to further his work.

\footnotetext{
61 Nishimura, Basic Study on the Citadel and Fort Sites of Dai Viet and Champa.

62 Ibid., $115^{-116 .}$
} 